\title{
THE USE OF SIMPLE CROWN TRAPS FOR THE INSECTS COLLECTION
}

\author{
Alexander B. Ruchin', Leonid V. Egorov ${ }^{1,2}$, Anatoliy A. Khapugin ${ }^{1,3}$, \\ Nikita E. Vikhrev ${ }^{4}$, Mikhail N. Esin ${ }^{5}$ \\ ${ }^{1}$ Joint Directorate of the Mordovia State Nature Reserve and National Park «Smolny», Russia \\ e-mail: ruchin.alexander@gmail.com \\ ${ }^{2}$ State Nature Reserve «Prisursky», Russia \\ e-mail:platyscelis@mail.ru \\ ${ }^{3}$ Tyumen State University, Russia \\ ${ }^{4}$ Lomonosov Moscow State University, Russia \\ ${ }^{5}$ Kozma Minin Nizhny Novgorod State Pedagogical University, Russia
}

Received: 23.11.2019. Revised: 21.12.2019. Accepted: 25.12.2019.

\begin{abstract}
The paper presents data on the use of simple crown traps for studying the insect fauna. The crown trap is a five-litre plastic container with a window cut out on one side of it at a distance of $10 \mathrm{~cm}$ from the bottom. The height of the trap location is from $2 \mathrm{~m}$ to $10 \mathrm{~m}$ from the soil surface. Fermenting beer, various dry wines with the addition of honey, jam or sugar were used as bait. It turned out that crown traps are an effective way to study the insect fauna of the upper layers of forests. During the field seasons of 2018-2019, specimens of the following 12 insect orders were caught in crown traps: Blattoptera, Dermaptera, Orthoptera, Heteroptera, Coleoptera, Lepidoptera, Trichoptera, Neuroptera, Raphidioptera, Mecoptera, Hymenoptera, Diptera. For trap establishment, it was better to choose places with the growth of deciduous trees secreting sap (Quercus, Acer, Fraxinus, Ulmus, Tilia). This trap type can be used to study the vertical insect distribution in forest systems, seasonal capture, and biotopic distribution. The use of crown traps is recommended during a comprehensive examination to supplement standard field methods. For example, when used properly, such traps can be an effective way of monitoring biodiversity and/or studying threatened insect species. We give seven recommendations to study the entomofauna using crown traps.
\end{abstract}

Key words: Arthropods, attraction, bait, fermenting beer, insects, insect collection method

\section{Introduction}

The study of the insect fauna of a certain region is usually carried out using a small set of methods which are well described in various manuals (e.g. Golub et al., 2012). The most popular methods are hand-picking, sweep net trapping, Barber traps, pitfall traps, light traps, Malaise traps, flight interception traps, cow manure-baited pitfall traps, rodent burrow pitfall traps (Jackman \& Nelson, 1995; Bouget et al., 2008; Worthington \& Larsen, 2010; Alekseev \& Shapoval, 2011; Vrdoljak \& Samways, 2012; Ali et al., 2015; Egorov \& Semishin, 2016; Jocque et al., 2016; McCravy et al., 2016; Alexeev \& Aleksanov, 2017; McCravy, 2017, 2018; Tomaszewska et al., 2018; Bulgakova \& Pyatina, 2019; Kazantsev et al., 2019; Krivosheina \& Krivosheina, 2019; Rozhnov et al., 2019; Ruchin et al., 2019). Recently, acoustic signals, automatic light traps, green Lindgren funnel traps, baited tube traps, emergence traps covering tree hollows, cryptozoan boards, and other trap types are widely used to determine the entomofauna (Dobony \& Edwards, 2001; Carrel, 2002; Quinto et al., 2013; Skvarla \& Dowling, 2017; Korb, 2018; McCravy, 2018; Ruchin \& Mikhailenko, 2018; Benediktov \& Belyaev, 2019).

Some collection methods are time-consuming. Therefore, entomologists rarely use them. At the same time, there is a simple and effective method using fermental traps (MacRae, 2015). This method is based on the attractiveness of a bait (e.g. a food source simulating a fermented sap) poured into a plastic cylindrical container (Allemand \& Aberlenc, 1991). Fermental traps with fermenting liquid baits (e.g. wine, molasses, beer with bananas, apples, sugar, and other natural fillers) have been shown to be effective 
in detecting many Coleoptera families (Williams et al., 1995; MacRae \& Rice, 2007; Guarnieri, 2009; Shapovalov, 2012; Wong \& Hanks, 2016; Redolfi De Zan et al., 2017; Egorov \& Ivanov, 2018). Similar traps, where the process of active fermentation of sugars is taking place, also attract some other insect groups, in particular Lepidoptera (Devries \& Walla, 2001; Dumbrell \& Hill, 2005; El-Sayed et al., 2005; Barlow et al., 2007; Uehara-Prado \& Freitas, 2009; Jakubikova \& Kadlec, 2015), Hymenoptera (Dvořák, 2007; Sorvari, 2013, 2019; Demichelis et al., 2014), Neuroptera (Duelli et al., 2006; Makarkin \& Ruchin, 2019), Diptera (Dvořáková, 2008; Dvořák, 2014; Dvořák et al., 2017) and a number of other insects (Hongayo et al., 2014), as well as Gastropoda (Lucid et al., 2018).

The effective use of such traps depends on many factors. In the present study, we have summarised the experience of using simple crown traps for collecting insects and discussing some methodological issues of their use.

\section{Material and Methods \\ Trap configuration}

Each trap consisted of a plastic five-litre container with a window cut into it on one side at a distance of $10 \mathrm{~cm}$ from the bottom (Fig. 1). A rope with an attached trap was thrown onto a tree branch at a height of 2 to $10 \mathrm{~m}$ from the soil surface with the help of a load. At lower heights, the trap can be attached at a tree branch without special loads. In each case, fermenting beer, various mixtures of dry wine with honey, jam or sugar were used as bait.

\section{The use of different baits}

In several series of experiments, we tried to find out whether sugar was important for attracting insects for determining the most attractive bait for different insect groups. The mixture for attraction consisted of liquids: beer, red and white wine, sugar added to them. Moreover, in the first series of experiments (five replicates), the following mixtures were studied: 1) beer with sugar (BS), 2) beer without sugar (B), 3) red wine with sugar $(\mathrm{RvS}), 4)$ red wine without sugar (Rv), 5) white wine with sugar (WvS), 6) white wine without sugar (Wv). In another series of experiments (five replicates) two variants of mixtures were studied: 1) beer with sugar and yeast, 2) beer with sugar without yeast. These experiments have been carried out from April to July. In each series of experiments, all traps were placed on oaks (Quercus robur L.) at the same height $(5.5-6 \mathrm{~m})$ at a close distance from each other (no more than $10 \mathrm{~m}$ ). Each repetition of the experiment (exposure) was carried out during 7-10 days (from April to July). Moreover, each repetition was conducted within one biotope. Studies were carried out in the Mordovia State Nature Reserve (Russia).
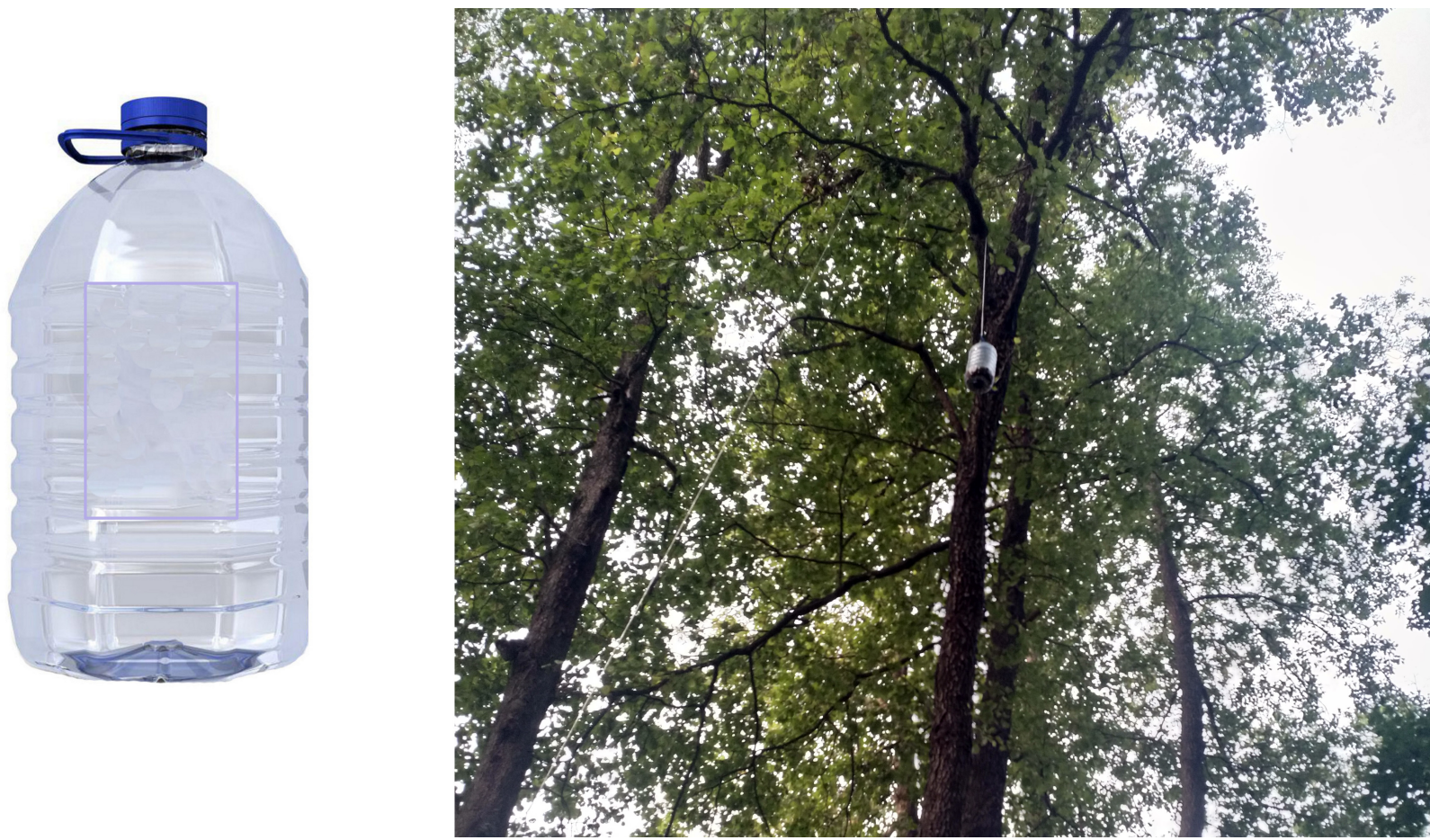

Fig. 1. The exterior of the crown trap (left) and its working position (right). 


\section{Seasonal collections}

In two series of experiments, we studied the possibility of capturing insects using crown traps during the field season. We established two traps at a distance of $5 \mathrm{~m}$ from each other in a pine (Pinus sylvestris L.) forest in the Mordovia State Nature Reserve at a height of $7 \mathrm{~m}(3 \mathrm{~km}$ from the village Pushta, Temnikov district, Republic of Mordovia, Russia). Traps were located on branches in the shade of tree crowns. The study site was represented by Pinus sylvestris forest with lime (Tilia cordata Mill.) participation. The forest stand (first layer) was composed by Pinus sylvestris trees. The second layer included Tilia cordata (projective cover of 65-70\%) and singular trees of birch (Betula pendula Roth). The shrub layer contained Acer platanoides L. (40$45 \%$ ), Tilia cordata saplings (8\%), Euonymus verrucosus Scop., Sorbus aucuparia L. The herb layer was composed predominantly by Carex pilosa Scop. with a projective coverage of $70 \%$ with participation of Glechoma hederacea L., Lathyrus vernus (L.) Bernh., Rubus saxatilis L., Asarum europaeum L., Dryopteris filix-mas (L.) Schott, Vicia sylvatica L., Convallaria majalis L., Aegopodium podagraria L., Pteridium aquilinum (L.) Kuhn, and Mercurialis perennis L. Such forest community was selected as it is one of the widely distributed habitats in the Mordovia State Nature Reserve (Khapugin, 2019) with a rich fauna (Ruchin \& Khapugin, 2019) and flora (Khapugin \& Ruchin, 2019) of threatened species. The collection period was from 25 April to 29 October 2019. We checked traps at intervals of 7 to 20 days. The weather conditions in the village Pushta were recorded. In the calculations, the data obtained by two traps were then averaged.

\section{The trap height}

The dependence of the height of trap location was studied in two series of experiment. Traps were hung on Quercus robur in a mixed forest in the Mordovia State Nature Reserve with moderately dense undergrowth. All traps were placed on Quercus robur within 10-12 m from each other. The study site was located at $200 \mathrm{~m}$ north of the village Pushta, quarter 446 of the Mordovia State Nature Reserve (54.7218 N, 43.2256 E). The selected forest community was conditionally divided into four layers. The first layer was represented by sparsely distributed Betula pendula trees (coverage is 10-15\%). There were large gaps between trees of the first layer. The second layer (upper of 3-4 m) was more clearly expressed and delimited from the first layer by the wide crowns of Quercus robur and Betula pendula. The projective cover of the second layer trees was $40-50 \%$. The shrub layer (from $0.7-1.0 \mathrm{~m}$ to $3.0-3.5 \mathrm{~m}$ ), including saplings of trees, was characterised by $50-60 \%$ projective cover. This layer consisted predominantly of Acer platanoides (25-30\%), Sorbus aucuparia (12-15\%), Frangula alnus Mill. (4-6\%), Tilia cordata (5-7\%), as well as Euonymus verrucosus, Lonicera xylosteum L., Amelanchier spicata (Lam.) K.Koch., saplings of Pinus sylvestris and Populus tremula L. The herb layer (up to $0.5 \mathrm{~m}$ ) has a projective cover about $30-40 \%$. The most dominating species were Calamagrostis arundinacea (L.) Roth (7-10\%), Glechoma hederacea (5-8\%), Melampyrum nemorosum L. (3-5\%), M. pratense L. (3-5\%), and Convallaria majalis $(2-3 \%)$. In addition, Hypericum perforatum L., Asarum europaeum, Viola mirabilis L., Poa nemoralis L., Carex digitata L., Melica nutans L., Aegopodium podagraria, Veronica chamaedrys L., Festuca pratensis Huds., Pimpinella saxifraga L., Pteridium aquilinum, Fragaria vesca L., and Achillea millefolium L. were registered there. The trap height was as follows: 1) the level of the middle of the undergrowth, 2) the level of the undergrowth height, 3) the level of the lower branches of the first forest layer, 4) the average level of the forest crown formed by the first forest layer. Beer was used with jam or sugar as bait. In all cases, the fluids were identical. Each repetition of the experiment (exposure time) was carried out for seven days. The first sampling period was from 01 July to 07 July 2019. The second sampling period was from 07 July to 14 July 2019.

\section{The number of traps}

In the first series of experiment, we studied the trapping rate dependence on the number of traps and the distance between them. At the same time, an analysis of the possible effect of tree species on the trapping rate was conducted. In this case, the traps were located at the forest edge in the botanical region-level natural monument «Tarkhanovskaya Dacha», (near the village Tarkhany, Temnikov district, Republic of Mordovia, Russia). It is a medium-sized woodland area surrounded by farmland (Fig. 2).

The main area was occupied by forest with a predominance of Quercus robur and Tilia cor- 
data. Populus tremula is included in the forest stand composition as an impurity or it forms small independent forest patches. The structure and floristic composition of plant communities are characteristic of broad-leaved forests, i.e. Quercus robur, Tilia cordata, Populus tremula were in the first layer with singular trees of Fraxinus excelsior L. and Acer platanoides. The shrub layer was represented by Corylus avellana L., Euonymus verrucosus and Lonicera xyloste$u m$. The herb layer was poorly developed under the closed forest crown. Many species of northern meadow steppes (e.g. Filipendula vulgaris Moench., Pyrethrum corymbosum L., Ranunculus polyanthemos L., Trifolium montanum L., Potentilla alba L., and Fragaria viridis Duch.) were located near the meadow-forest borders, on the open slopes among the abundant forbs' vegetation. Traps were hung at the southern forest edge in Quercus robur, Acer platanoides and Fraxinus excelsior trees at the same height of $7-8 \mathrm{~m}$. The distance between the traps was different (Fig. 2).

\section{Exposure time}

The dependence of trapping rate on the exposure time of traps was studied in a series of experiments. Traps were exposed from two to ten days in one biotope at a distance of 15-20 m from each other. The height of all traps in Quercus robur was 5-6 $\mathrm{m}$. The study was conducted in July in the Temnikov district of the Republic of Mordovia (Russia).

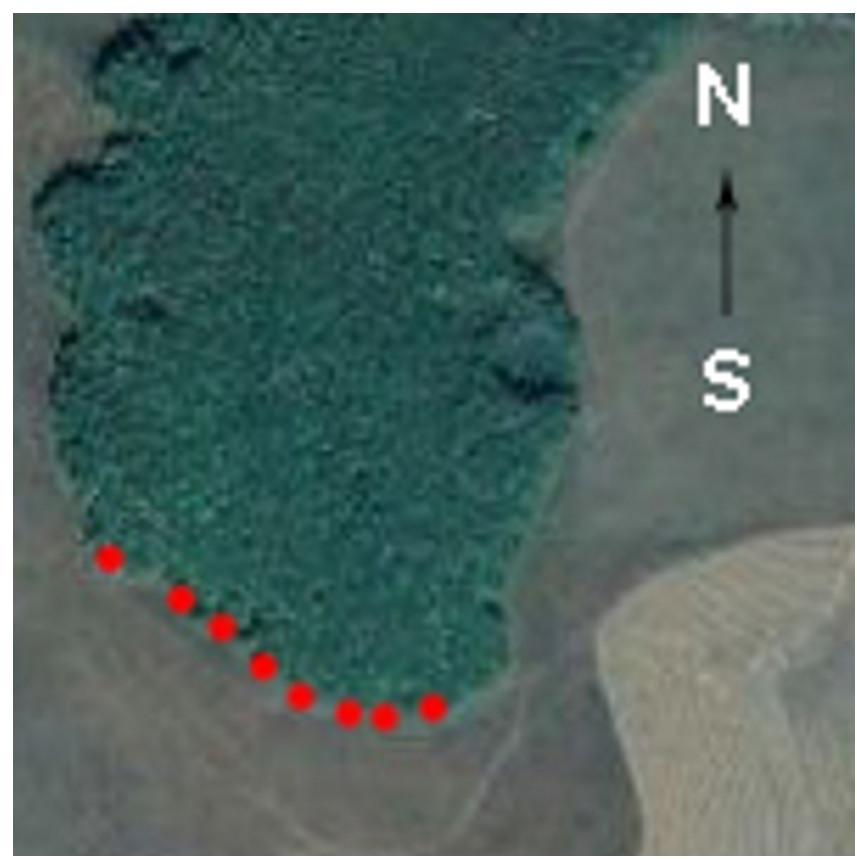

Fig. 2. The location of traps (indicated by red dots) in the study area (near the village Tarkhany (Republic of Mordovia, Russia).

\section{Conducted calculations and used terms}

We applied a multivariate analysis to investigate the differences and similarities in the structure of insect assemblages among the heights of trap location. Nonmetric multidimensional scaling (NMDS) ordination was performed on Bray-Curtis similarity matrices using the obtained data. We used SIMPER (similarity percentage) analysis to assess the contribution of various insect orders to the differences in the taxonomical composition of samples obtained by traps located at different heights. We used violin plots with boxplots. The boxplots represent the graphical representation of the median (horizontal line in the «box» of boxplots), 25\% and $75 \%$ of the quartiles (box) 1.5 times the height of the box height (horizontal lines at the end of the whiskers) as well as remote observations (outliers, a ring means that the value is more than 1.5 times the range of values in the box and an asterisk that the value is more than three times larger). The violin plots were used to show the distribution of specimens' number of different insect orders by indicating the data density mirrored and flipped over. We analysed differences in the trap effectiveness by insect orders, which have a relative abundance of more than $5 \%$ in the sample from the sampling period. All analyses and graphical outputs were performed using the PAST software (ver. 3.19; Hammer et al., 2001).

The effectiveness of baits was evaluated on the basis of the presence of the total number of individuals caught. The following terms are used in the article:

Occurrence - the ratio of the number of samples where a species (taxonomic group) is present to the total number of samples (expressed in \%).

Exposure time - the period between hanging a trap and taking samples for analysis (expressed in days).

The bait (agent) is an insect-attracting liquid trapped and consisting of various mixtures (beer, wine, water) and natural fillers in the form of solid and liquid food additives (sugar, honey, jam).

\section{Results and Discussion}

Traps have been exposed during 2018 (June to August) and 2019 (April to October) in five regions: Republic of Mordovia, Chuvash Republic, Nizhny Novgorod region, Ulyanovsk region, and Penza region. A large number of 
insect taxa and specimens was caught in those traps. We did not count all the insects in all the traps. The total number of traps exposed was more than 350 over two years. We counted all taxa in only 170 traps. In these traps, 50489 individuals were caught. They were represented by species belonging to 12 orders: Blattoptera, Dermaptera, Orthoptera, Heteroptera, Coleoptera, Lepidoptera, Trichoptera, Neuroptera, Raphidioptera, Mecoptera, Hymenoptera, Diptera (Fig. 3).

The number of insects caught during the long exposure of the trap could be estimated at hundreds per trap. Many insect groups were well preserved in the traps we used. Among Coleoptera, Scarabaeidae, Cerambycidae, Nitidulidae, and Staphylinidae were well and constantly attracted by the established traps. Species of Coccinellidae, Cantharidae, Eucnemidae, Elateridae, Chrysomelidae, Silphidae, and Curculionidae were found irregularly in the traps. However, such groups as Lepidoptera species, despite their large numbers, were poorly preserved during prolonged exposure and are difficult to identify. We recommend another trap type for collecting butterflies. In these traps, beer or wine were used as bait (Jalas, 1960). Among Diptera, many Calliphoridae and Muscidae were found. Families developed on flowing sap and in tree cavities (Nematocera and Drosophilidae) were well represented in the traps. Among Hymenoptera, Vespidae insects were regularly caught in the traps. Formicidae, Chrysididae were occasionally caught in low-lying traps. Species of Mecoptera and Neuroptera were often found.

Species of Blattoptera, Raphidioptera, Dermaptera, Orthoptera, Heteroptera, and Trichoptera in traps were less abundant. It seems that with such a small number, they are trapped accidentally. However, in a certain season and at certain stations, representatives of Blattoptera, Raphidioptera, Dermaptera, and Trichoptera were constantly caught. We are sure that only representatives of Orthoptera and Heteroptera were randomly caught.

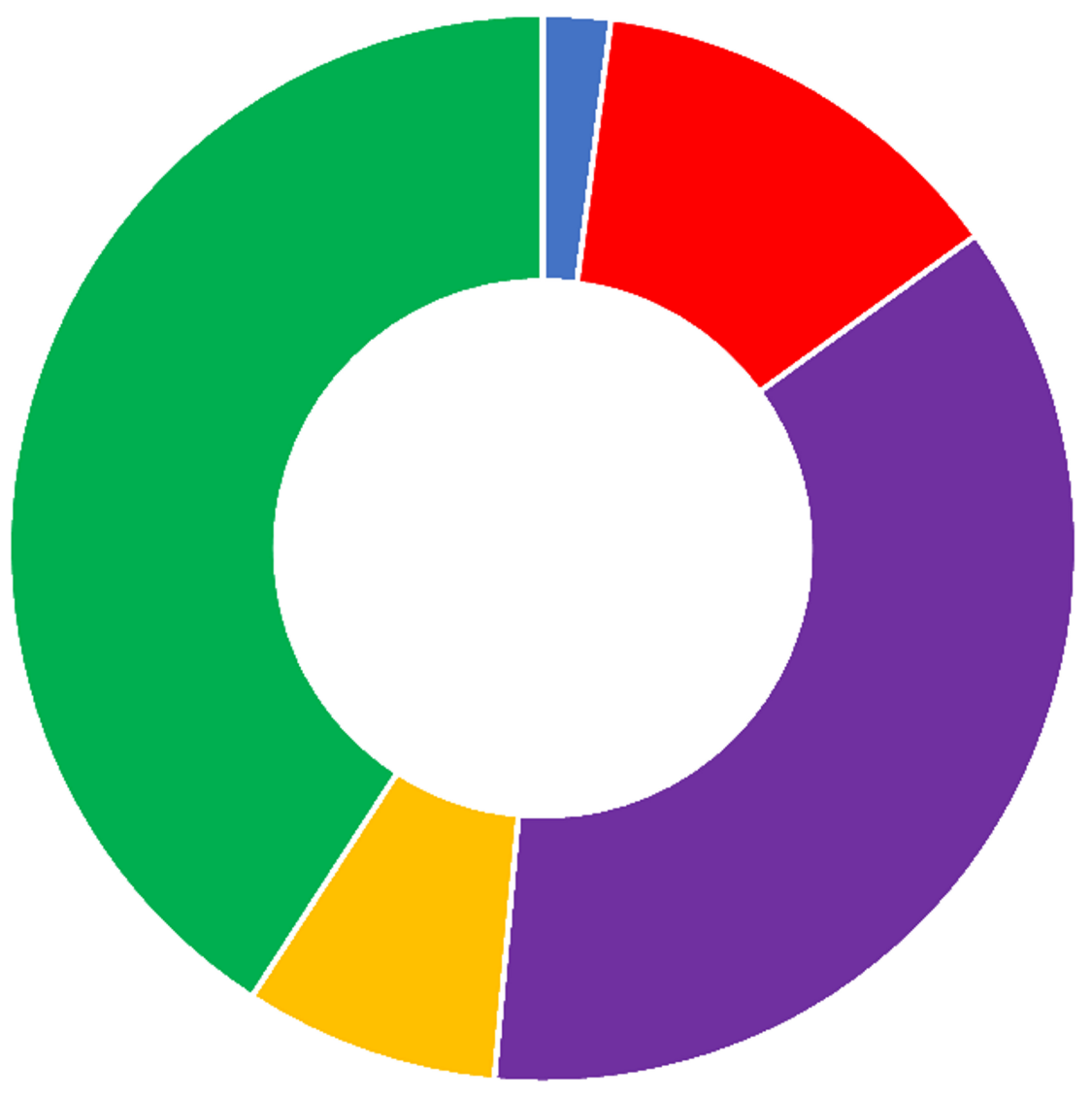

\section{$\square$ Coleoptera $\square$ Lepidoptera $\square$ Hymenoptera $\square$ Diptera $\square$ Others}

Fig. 3. Taxonomic composition and ratio of orders caught by crown traps. Note: Category «Others» includes the following orders: Neuroptera (715 specimens; $1.42 \%$ of total number of caught specimens), Heteroptera $(106 ; 0.21 \%)$, Mecoptera (82; $0.16 \%)$, Blattoptera (42;0.08\%), Dermaptera (34; 0.07\%), Orthoptera (25;0.05\%), Trichoptera (19; 0.04\%), Raphidoptera (12;0.02\%). 
Dependence of capture effect from attracting liquids

The composition of the bait depends on the duration of the capture and the goal pursued. The bait quality can affect numbers of both individuals and species caught by traps (Utrio \& Eriksson 1977; Sourakov \& Emmel 1995; Sussaenbach \& Fiedler, 1999; Laaksonen et al., 2006). Several effective bait recipes have been identified in a number of studies. For example, while studying two attracting compounds in traps, it turned out that during September and October pineapple attracted Scyphophorus acupunctatus Gyllenhal, 1838, more than fermented maguey (Valdés et al., 2005). Different bait compositions were tried. In some traps sweet wine was applied. In others, a combination of ripe banana with non-alcoholic beer was used (Ali et al., 2015).

For trapping in the tropics, Brazilian scientists recommended a wide variety of fluids and ingredients (Freitas et al., 2014). However, there is a better-known bait called «standard bait». In the Neotropics, the traditional, widely used and successfully employed bait in trap studies is a mixture of mature banana (processed, hand mashed or in pieces) with sugar cane juice, fermented to become attractive to fruit-feeding butterflies. This mixture type has a number of practical advantages. This is attractive for all butterflies eating the fruit. It is easy to prepare, and has a long shelf life. In some studies, beer and rum were used as an addition to the standard bait (Daily \& Ehrlich, 1995).

However, there are other data. Pettersson \& Franzén (2008) used beer and wine as bait. They concluded that both bait types are good to catch butterflies. The choice of bait primarily depends on the taste, cost, and availability of ingredients. Both baits showed appropriate results. There were no statistically significant differences in indicators either in the number of captured species or in the total number of individuals.

Some chemical compounds, such as turpentine, alcohols, esters or organic acids, may also be attractive to certain insect groups. For example, grape juice, sugarcane molasses, and a solution containing brown sugar were used to attract the butterfly Grapholita molesta (Busck, 1916). Of all the Ajar / TAS variants (this is an Ajar trap with a solution containing brown sugar $(8.69 \%)$ and terpinyl acetate $(0.05 \%)$ solution $)$ can be used to maximise the species appearance in apple orchards (Padilha et al., 2018). Laboratory choice tests were conducted to compare attractiveness of vinegar, ethanol, apple juice, the vinegar-ethanol mixture, vinegar-apple mixture, ethanol-apple mixture and vinegar-ethanol-apple mixture in relation to Eucryptorrhynchus scrobiculatus (Motschulsky, 1853). It turned out that the vinegar-ethanol-apple mixture is much more effective than the rest of the blends (Yang et al., 2019).

Thus, the number of caught specimens (hereafter - catch index) in traps with baits are clearly biased towards species attracted by specific baits (Ausden \& Drake 2006). Hence, the bait selection is crucial in the sampling design relevant to the target insect group.

In our study, we used several mixtures on the basis of red wine, white wine or beer. Sugar and yeast were added to this bait. From late May to early July, Blattoptera, Heteroptera, Coleoptera, Lepidoptera, Neuroptera, Mecoptera, Hymenoptera, and Diptera were attracted by various wines and beer (Fig. 4).

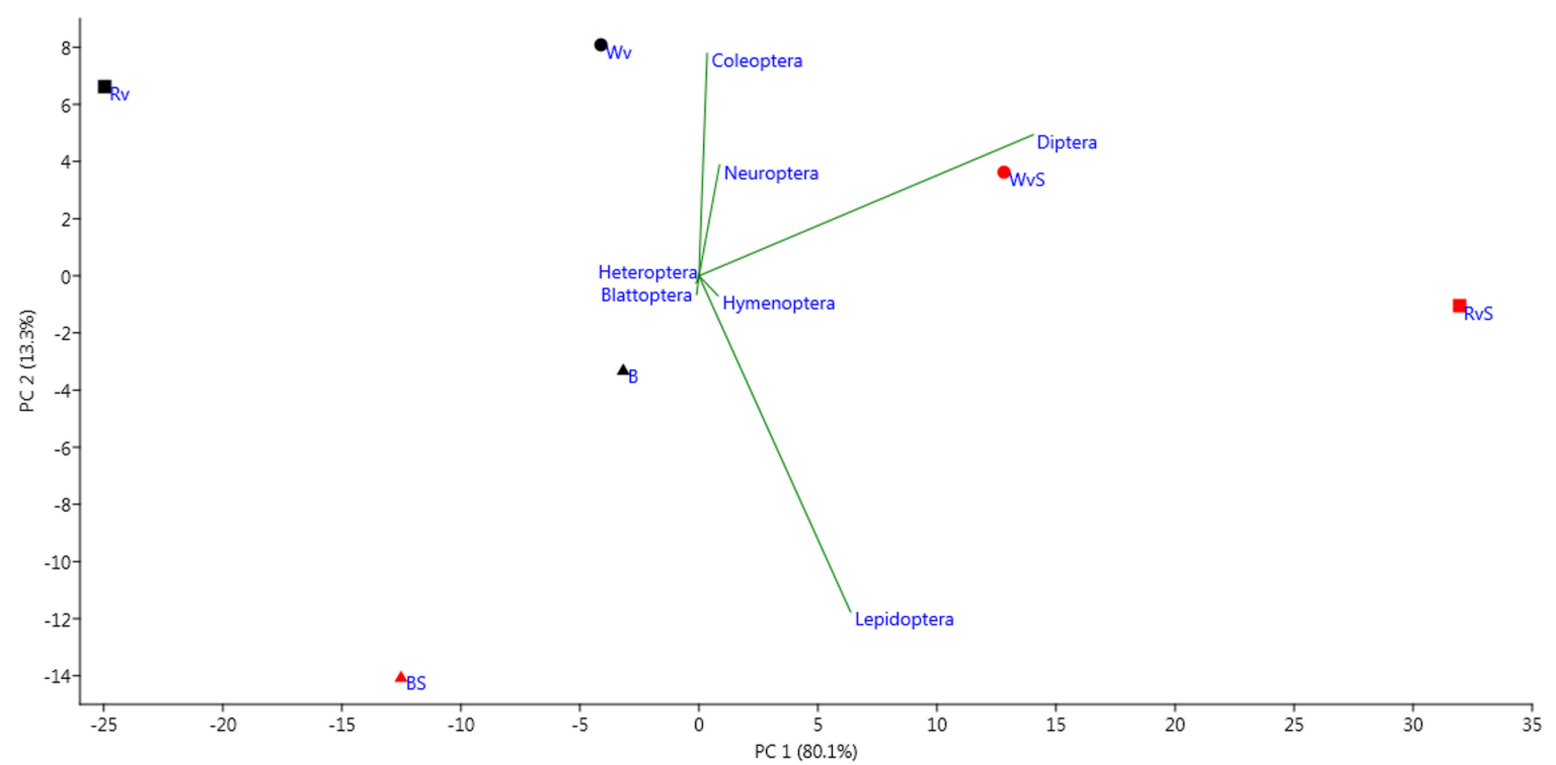

Fig. 4. Distribution of captured specimens of insect orders depending on various attracting liquids. Designations: BS - beer with sugar; B - beer without sugar; RvS - red wine with sugar; Rv - red wine without sugar; WvS - white wine with sugar; $\mathrm{Wv}$ - white wine without sugar. 
Fig. 4 shows that the arrows of biplot graph indicated an increase in factor strength for Diptera and Lepidoptera, as well as for Hymenoptera in the direction of white wine with sugar and red wine with sugar. This means that using wine (white or red) with sugar increased the proportion of Diptera, Lepidoptera, and Hymenoptera specimens caught in the sample. On the graph, the mixtures of white wine with sugar and red wine with sugar were located separately of other mixtures and, in turn, not far from each other. The same situation was with the arrangement of white wine without sugar and red wine without sugar in Fig. 4. This supposes that there was no significant difference in the use of red or white wine, while the presence of sugar matters. While the arrows of Diptera, Lepidoptera, and Hymenoptera were directed towards white and red wine with sugar, if we continue these arrows in the opposite direction from the centre of all biplot graph arrows, then white wine and red wine without sugar will be located in this direction. This means that if these mixtures are used, the number of individuals of Diptera, Lepidoptera, and Hymenoptera will decrease or at least it will be lower than in the case with the use of wines with sugar. According to some other observations, the most effective bait was wine for Scatopsidae (Diptera), beer and wine for Drosophilidae (Diptera). However, no significant difference between baits for Anisopodidae was found (Manko et al., 2018). Grapes and beer turned out to be the most effective baits for capture of Tephritidae species (Bharathi et al., 2004).

In mixtures, sugar obviously played a more significant role for Lepidoptera and Hymenoptera. The arrows of the biplot graph for these orders were directed towards the beer-sugar mixture, while the size of all other taxonomic groups decreased in the case of using both beer with or without sugar. Sussaenbach \& Fiedler (1999) pointed out that sugar was necessary for catching butterflies. The authors demonstrated that almost two times more species and almost ten times more individuals were attracted to sugar in compare to banana bait.

The Coleoptera and Neuroptera showed a similar predisposition to the mixtures used. Fig. 3 shows that the abundance of species from these orders was lower when beer with or without sugar was used. At the same time, a higher predisposition of Coleoptera and Neuroptera to white wine without sugar and partly to red wine without sugar was shown. Traps with red wine, white wine, and sugar also showed the highest detection probabilities for Coleoptera species belonging to the genera Dorcus, Protaetia, and Cetonia (Bardiani et al., 2017).

Other groups (Heteroptera and Blattoptera) were represented by a very small number of individuals. At two locations of the Mordovia State Nature Reserve, we compared beer-sugar mixtures with and without yeast. We hypothesised that the yeast use led to fermentation of the beer-sugar mixture, while the fermentation of baits without yeast would start later. Location 1 was located at the forest edge, while location 2 was situated under the forest canopy. The distance between the locations was $300 \mathrm{~m}$. In location 1, our experiment had four repetitions, while it was conducted in two repetitions in location 2. The comparison of data obtained in two locations was conducted using NMDS analysis. It demonstrates remarkable difference between the data obtained at the edge of the forest and under the forest canopy (Fig. 5).

Most probably, so remarkable differences between tested locations could be explained by differences in catch index of insects at both locations. SIMPER analysis (Table 1) indicated that the orders Diptera (average dissimilarity contribution (ADS) - 57.3\%) and Lepidoptera (ADS - 27.3\%) had the highest contribution in dissimilarity between both locations. Table 1 demonstrates that the mean abundance values of these orders differ remarkably between location 1 and location 2 . To a certain extent, it is applicable to Hymenoptera, which also contribute (ADS $-4.7 \%$ ) to differences between locations tested.

Then we tested the applying of different mixtures. The comparison of obtained data using NMDS analysis shows insignificant differences between sugar-beer baits with and without yeast (Fig. 6). These results underline no influence of yeast in beer-sugar mixtures on the catch index for insects. Perhaps, sugar plays a more significant role in attracting insects than substances released into bait during the fermentation process.

SIMPER analysis (Table 2) indicates the relatively low contributions of insect orders into difference between types of baits (Table 2), although Diptera, Lepidoptera and Hymenoptera have the highest ADS. The obtained results coincide with non-remarkable difference between the mean values of the catch index in almost each insect order. Only the Diptera order forms an exception. Its catch index was 2-fold higher using beer-sugar bait without yeast compared to beer-sugar bait with yeast (Table 2). 


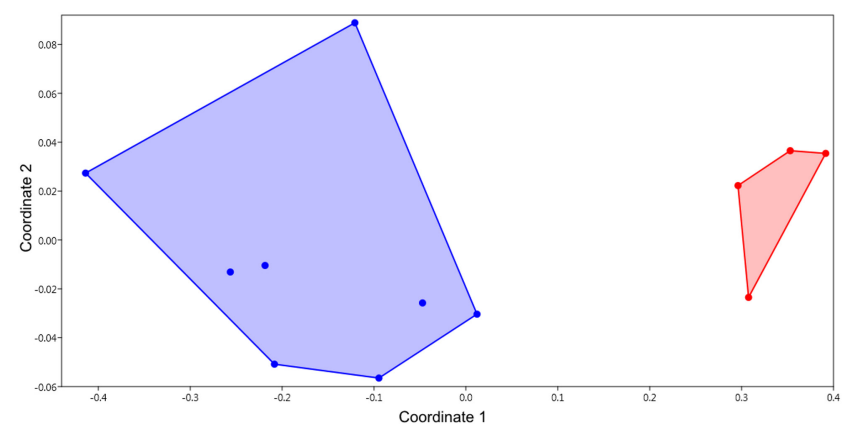

Fig. 5. Ordination diagram of the abundance of insect orders among the location 1 (blue dots) and location 2 (red dots) (3D NMDS; $1+2$ plot axes; locations as explanatory variables).

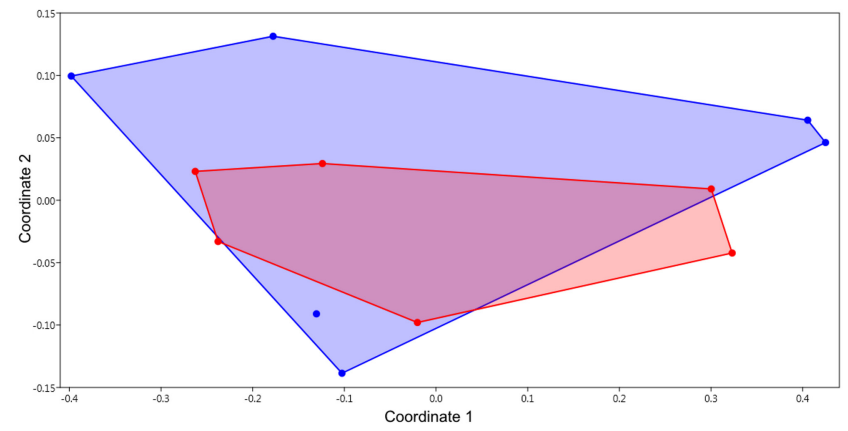

Fig. 6. Ordination diagram of the abundance of insect orders among the beer-sugar mixtures with (blue dots) and without (red dots) yeast (3D NMDS; $1+2$ plot axes; mixtures as explanatory variables).

Table 1. Similarity percentage analysis (SIMPER) of the taxonomical structure (order level) of insect assemblages among the locations tested

\begin{tabular}{|l|c|c|c|c|c|}
\hline \multicolumn{1}{|c|}{ Taxon } & Average dissimilarity & Contribution \% & Cumulative \% & Mean Pushta & Mean Forest \\
\hline Diptera & 57.33 & 62.19 & 62.19 & 1.63 & 161 \\
\hline Lepidoptera & 27.5 & 29.84 & 92.03 & 0.625 & 69.5 \\
\hline Hymenoptera & 4.692 & 5.09 & 97.12 & 4.63 & 17.5 \\
\hline Coleoptera & 1.392 & 1.511 & 98.63 & 4.63 & 4.25 \\
\hline Neuroptera & 0.6018 & 0.6528 & 99.28 & 0 & 1.5 \\
\hline Heteroptera & 0.5484 & 0.5949 & 99.88 & 0.25 & 1.5 \\
\hline Blattoptera & 0.1124 & 0.1219 & 100 & 0 & 0.25 \\
\hline
\end{tabular}

Table 2. Similarity percentage analysis (SIMPER) of the taxonomical structure (order level) of insect assemblages among the baits tested

\begin{tabular}{|l|c|c|c|c|c|}
\hline \multicolumn{1}{|c|}{ Taxon } & Average dissimilarity & Contribution \% & Cumulative $\%$ & Mean BS & Mean BSY \\
\hline Diptera & 31.89 & 48.26 & 48.26 & 75.2 & 34.5 \\
\hline Lepidoptera & 14.49 & 21.93 & 70.19 & 23 & 24.2 \\
\hline Hymenoptera & 11.46 & 17.34 & 87.53 & 10.2 & 7.67 \\
\hline Coleoptera & 6.749 & 10.22 & 97.75 & 3.83 & 5.17 \\
\hline Heteroptera & 1.126 & 1.704 & 99.45 & 0.333 & 1 \\
\hline Neuroptera & 0.3017 & 0.4567 & 99.91 & 0.333 & 0.667 \\
\hline Blattoptera & 0.06076 & 0.09195 & 100 & 0 & 0.167 \\
\hline
\end{tabular}

Note: BS - beer-sugar mixture without yeast, BSY - beer-sugar mixture with yeast.

Dependence of catch index on the season and weather conditions

Experiments showed (Allemand \& Aberlenc, 1991) that rain and temperature were two significant factors influencing the trap attractiveness. Rain, especially during thunderstorms, can dilute the bait and, therefore, reduce its attractiveness. The temperature does not affect so much the bait in contrary to activity of insects as ectothermic animals. Low temperature limits the trap effectiveness by reducing the insect flight activity. This is only possible if the temperature is above a certain threshold. A significant positive correlation was found between the number of attracted noctuid moths, species number, and temperature (Sussaenbach \& Fiedler, 1999). Ribeiro \& Freitas (2010) found a positive relationship between the average temperature and wealth and the abundance of captured butterflies. Grøtan et al. (2012) also found a positive relationship between butterfly abundance and temperature and rainfall, as well as a negative relationship between insect diversity and rainfall. 
Wind speed can also affect catch index. On the one hand, higher wind speed and the accompanying more powerful convective cooling inhibit the insect flight activity. On the other hand, due to the wind the bait smell spreads more freely and reaches much further. Studies demonstrated that wind has a significant effect on the specimens' number of noctuid moths, but not on the species number (Sussaenbach \& Fiedler, 1999).

In our study, the captures were carried out from 25 April to 29 October 2019 in a typical pine forest in the Mordovia State Nature Reserve. A total of 4862 specimens from nine insect orders (Blattoptera, Heteroptera, Coleoptera, Lepidoptera, Neuroptera, Trichoptera, Mecoptera, Hymenoptera, and Diptera) were recorded in two series of experiments. The largest number of caught individuals was distinguished by the orders of Lepidoptera, Diptera, and Coleoptera. Their proportion exceeded $95 \%$ of all caught individuals. Throughout the season, representatives of only three orders fell into traps: Lepidoptera, Hymenoptera, and Diptera (Fig. 7).

The dynamics of the Coleoptera abundance was one-peaked. In May, we observed a sharp increase in the abundance of this group. Then the abundance gradually decreased. In late September - early October, Coleoptera were no longer trapped (Fig. 8, Fig. 9). The number of Lepidoptera falling into traps varied unevenly and was three-peaked. The maximum number of insects was found in mid-June.

The dynamics of the Diptera assemblages was two-peaked with maximum peaks in late June and late August. The June peak is indicated by similar Diptera catch index values observed in the Czech Republic (Dvořák, 2014). In October, under a temperature increasing in $10-15^{\circ} \mathrm{C}$, Diptera were caught again into the trap more often. The Hymenoptera (mainly Vespidae) abundance was high in May with a consequent declining, and again increasing in August and September. Representatives of the Chrysopidae family (Neuroptera order) were attracted by traps. The largest number of caught Neuroptera individuals was observed in late July and August. According to Duelli et al. (2006), it was during a peak in the abundance of this group. The number of insect orders caught by traps had a maximum in June (6-7 orders) and in late July - August (6 orders).

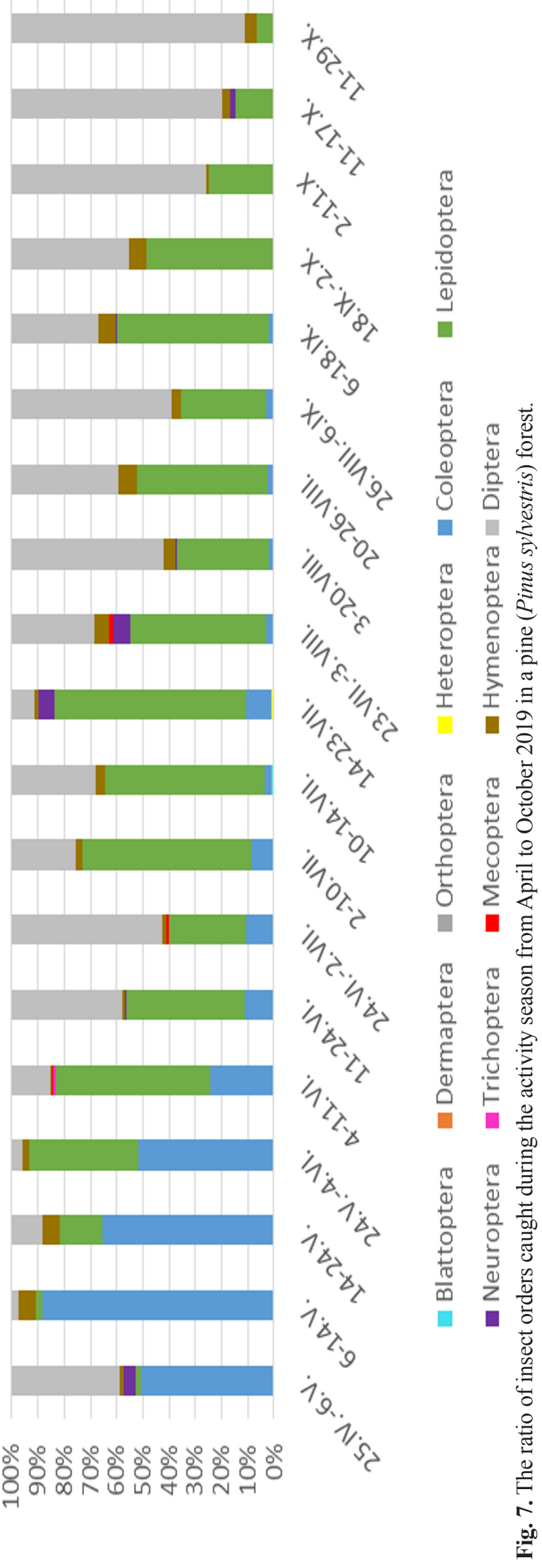




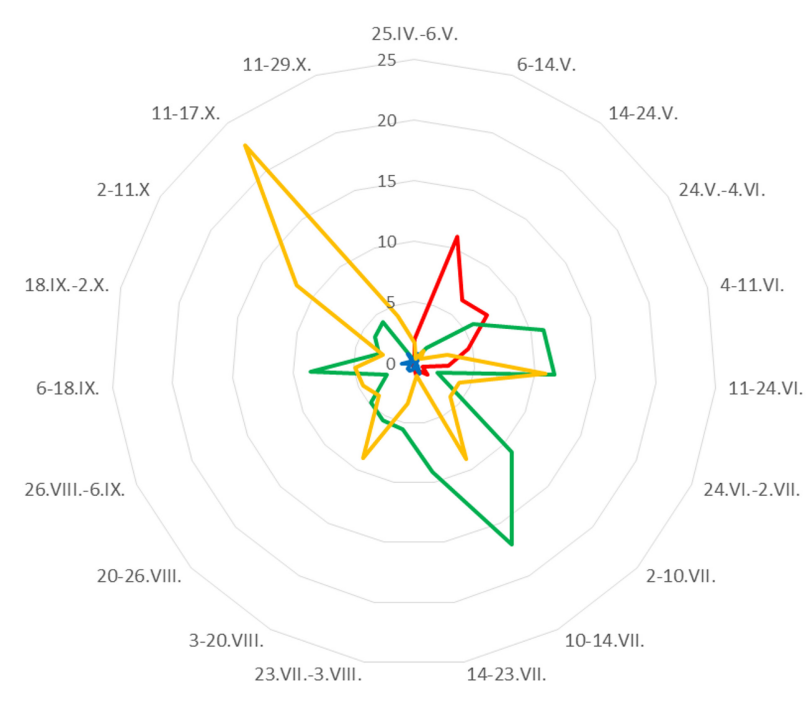

Fig. 8. Seasonal dynamics of the number of individuals in four insect orders attracted by traps (per one day of exposure) in a pine (Pinus sylvestris) forest.

By testing a possible impact of certain meteorological factors, we revealed that pronounced trends did not appear. We can only talk about some dependencies (Fig. 8). For example, in May, a distinct peak of Coleoptera abundance was observed during a sharp increase in day and night temperature and a corresponding decrease in humidity. However, the further increase in temperature in the summer months no longer had a special effect on catching this group by traps. The first (June) peak of Lepidoptera abundance was also apparently associated with an increase in both night and day temperature values. However, in July, an even larger increase in the Lepidoptera abundance can be explained only by a stably high night temperature, which allows species attracted by fermenting solutions in traps to be quite active. Diptera was also influenced by temperature. But this schedule was quite variable. On the other hand, an increase in day temperature in October sharply increased the Diptera abundance in crown traps.

In our opinion, this trap type can be used to study the seasonal activity cycles of some insects (e.g. phenological studies). It especially concerns Coleoptera and Diptera, which are well preserved during capture and can be subsequently identified by specialists.

The trapping rate dependence on traps height

Traps with attracting liquids established at various heights have been tested in the USA

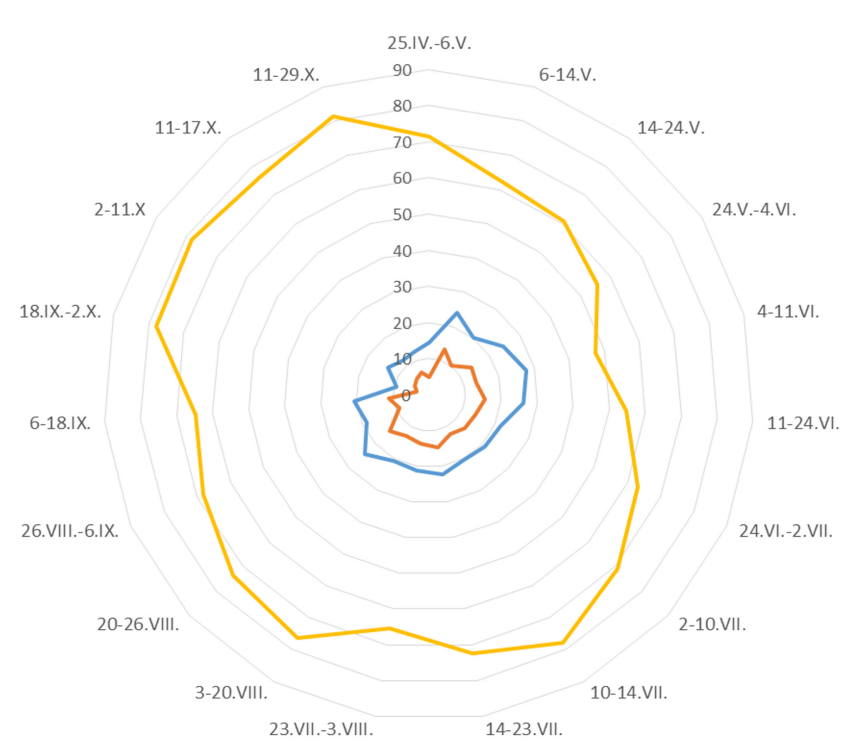

— daily temperature, $\mathrm{c}$ — night temperature, $\mathrm{c}$

Fig. 9. The dynamics of day and night temperature values and humidity registered in a pine (Pinus sylvestris) forest during the study period.

(Dodds, 2014). The author demonstrated that species diversity, abundance, and number of unique species were higher in traps located in undergrowth layer compared to ones situated in canopy layer. The number of individual species and the species composition of the entomofauna itself varied depending on the height of the trap location. In another study, Schmeelk et al. (2016) established the traps at three height types: understory $(1.5 \mathrm{~m})$, lower canopy $(6 \mathrm{~m})$, and mid-canopy $(12 \mathrm{~m})$. In total, the authors caught 50 Cerambycidae species, seventeen of which were the most common. The remaining species were noted by a few specimens. Moreover, there was a number of different baits attracting 13 of the widespread species. Three species were captured primarily in understory traps, while another five species were primarily caught in mid-canopy traps. The variation among Cerambycidae species in their vertical distribution in forests explained similar overall abundance and species richness across trap height treatments. Data on poorly studied Coleoptera species can be obtained using traps located at higher heights. For some of these species, the geographical distribution (in particular, their northern range boundary) could be identified depending on their environmental preferences (Allemand \& Aberlenc, 1991). In temperate forests, the proportion of saprophagous beetles is higher in lower forest layers, while in tropical forests, it increases with the 
height of trap location on tree trunks. This is associated with a higher competition between separate insect groups in each forest layer of tropical forests (Weiss et al., 2019).

During the study period (from 01 July to 14 July 2019), our traps caught 1580 insect individuals, i.e. 732 individuals in the first sampling period and 848 individuals in the second sampling period. In both sampling periods, the following orders were represented in the traps: Lepidoptera, Diptera, Hymenoptera, Coleoptera, Neuroptera, Heteroptera, and Blattoptera.

A non-metric multidimensional scaling indicates that differences in the taxonomical composition between two sampling periods are more pronounced than between selected heights of trap location (Fig. 10). Different sizes of convex hulls at the NMDS plot indicate the higher differences in abundance of caught insects during the first sampling period compared to the second sampling period. According to the SIMPER analysis, the abundance of Diptera and Lepidoptera explains most of the differences in the taxonomical structure of samples according to used heights of trap location (more than $89 \%$ dissimilarity in the sum of both sampling periods) (Table 3). Among the obtained orders, Diptera and Lepidoptera have a relative abundance higher than 5\%. These orders have also a higher contribution to the dissimilarity between sampling periods with different heights of trap location (Table 3 ).

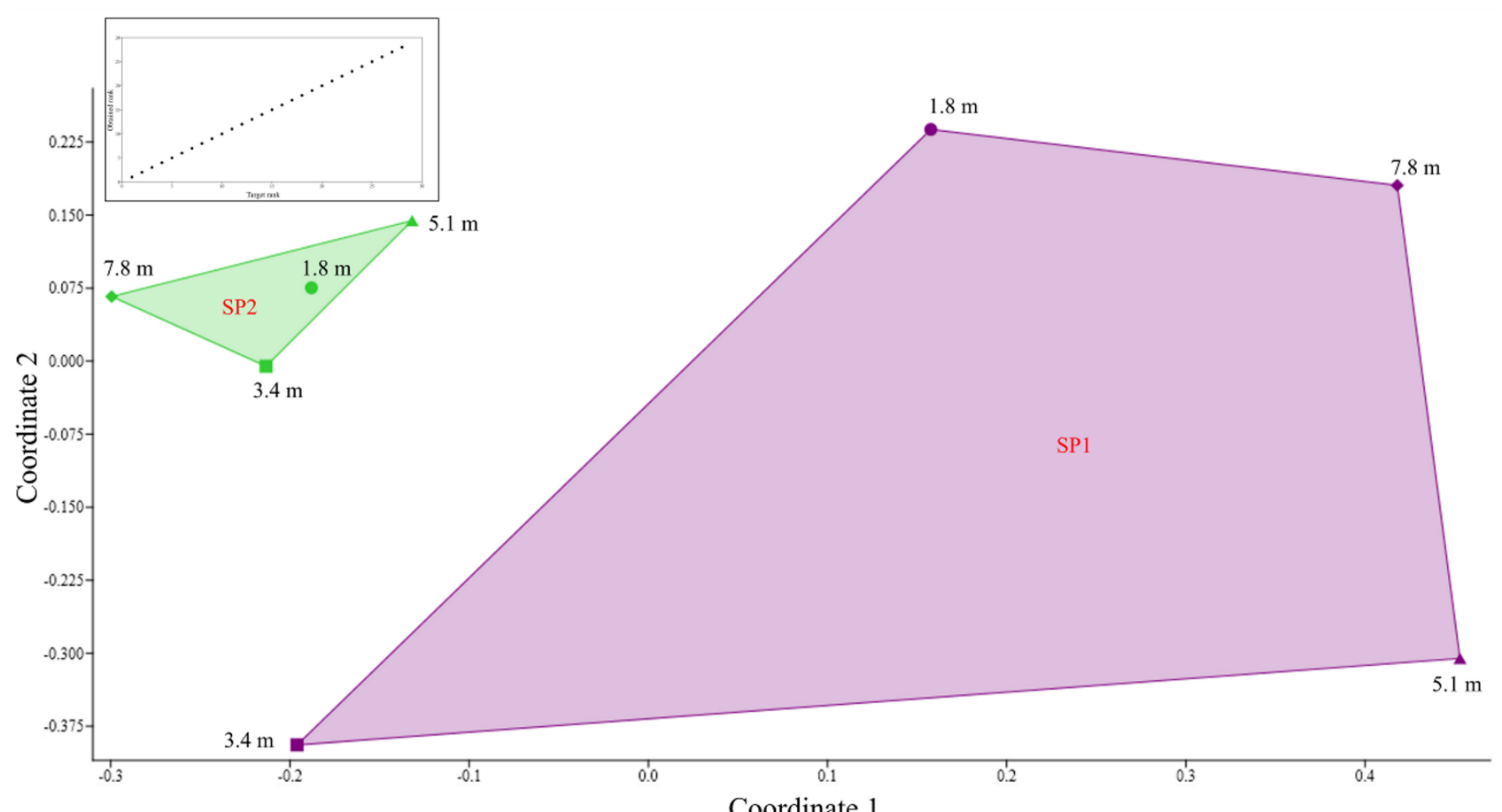

Fig. 10. Non-metric Multidimensional Scaling (NMDS) ordination diagram of the taxonomical structure (order level) of insect assemblages among the heights of trap location from both sampling periods (2D NMDS; $1+2$ plot axes; heights of trap location as explanatory variable; Shepard plot in the upper left corner of the diagram; sampling sites coding: dot - height: 1.8 $\mathrm{m}$, filled square - height: $3.4 \mathrm{~m}$; filled triangle - height: $5.1 \mathrm{~m}$; filled diamond - height $7.8 \mathrm{~m}$ ).

Table 3. Similarity percentage analysis (SIMPER) of the taxonomical structure (order level) of insect assemblages among the heights of trap location in both sampling periods

\begin{tabular}{|l|c|c|c|c|c|c|c|}
\hline \multicolumn{1}{|c|}{ Order } & Average dissimilarity & Contribution \% & Cumulative \% & Mean $1.8 \mathrm{~m}$ & Mean 3.4 m & Mean 5.1 m & Mean $7.8 \mathrm{~m}$ \\
\hline Lepidoptera & 16.88 & 56.08 & 56.08 & 110 & 153 & 82.5 & 116 \\
\hline Diptera & 10.07 & 33.44 & 89.53 & 42.5 & 105 & 71.5 & 40.5 \\
\hline Hymenoptera & 1.423 & 4.728 & 94.25 & 10 & 11.5 & 4.5 & 5.5 \\
\hline Neuroptera & 0.9808 & 3.259 & 97.51 & 2.5 & 10.5 & 3 & 2.5 \\
\hline Coleoptera & 0.5302 & 1.761 & 99.27 & 3.5 & 3.5 & 6.5 & 5 \\
\hline Blattoptera & 0.1142 & 0.3794 & 99.65 & 0 & 1 & 0 & 0 \\
\hline Heteroptera & 0.1042 & 0.3462 & 100 & 0 & 0.5 & 0 & 0.5 \\
\hline
\end{tabular}


Our results confirm unequal effectiveness of traps located at different heights for different orders. Fig. 11 shows that the height of $3.4 \mathrm{~m}$ was highly different to others heights in the PCA plot. At the same time, extreme heights of $1.8 \mathrm{~m}$ and 7.1 $\mathrm{m}$ were closely located in a plot, while a height of $5.1 \mathrm{~m}$ was located apart from other heights. This picture is most probably explained by the highest effects of the orders Diptera and Lepidoptera (Table 3 ) on the total taxonomic structure of insects caught during the experiment. Studying the occurrence of noctuid moths on various baits at two heights of $0.5 \mathrm{~m}$ and $2.0 \mathrm{~m}$ demonstrated that in the first case all bait types were the least effective, while most of the caught species were found at a height of $2.0 \mathrm{~m}$ (Sussaenbach \& Fiedler, 1999). Indeed, the heights of $1.8 \mathrm{~m}$ and $7.8 \mathrm{~m}$ were located closely due to the lowest Diptera abundance at these heights.

At the same time, the separate location at a height of $5.1 \mathrm{~m}$ in Fig. 11 is most probably explained by the lowest abundance of Lepidoptera caught at this height. Finally, the most distinct location of height $3.4 \mathrm{~m}$ is undoubtedly caused by the highest abundance of the most influencing orders Lepidoptera and Diptera together with the highest specimens' number of Blattoptera (captured only at the $3.4 \mathrm{~m}$ height), Hymenoptera, Neuroptera, Heteroptera caught at this height (Table 3). Therefore, most orders were represented by a maximum of specimens' number captured at the height of 3.4 $\mathrm{m}$, except for Coleoptera, which maximal specimens' number was at a height of $5.1 \mathrm{~m}$ (Table 3 ).
The taxonomic composition of Coleoptera and Diptera attracted by the trap has been studied separately (Fig. 12, Fig. 13). It is well known that some Coleoptera families and separate species have a clear preference for a certain forest layer (Su \& Woods, 2001; Ulyshen, 2011; Procházka et al., 2018; Sheehan et al., 2019). A three-year study of the bait impact on Cerambyx cerdo Linnaeus, 1758 (Coleoptera) in Italy showed that this species was more common at a height of $10 \mathrm{~m}$ than at a height of $2 \mathrm{~m}$ (Redolfi De Zan et al., 2017). Traps in the forest understory caught the highest specimens' number of Xylotrechus colonus (Fabricius, 1775) and Graphisurus fasciatus (DeGeer, 1775), whereas more adults of Neoclytus mucronatus mucronatus (Fabricius, 1775) were caught in the forest canopy rather than in the understory layer (Wong \& Hanks, 2016).

During the exposure, species from four families Staphylinidae, Scarabaeidae, Nitidulidae, and Cerambycidae were caught in our traps (Fig. 12). We found that Nitidulidae (Epuraea sp., Cychramus luteus (Fabricius, 1787) and Cryptarcha strigata (Fabricius, 1787)) were more often caught at heights of $3.4 \mathrm{~m}$ and $5.1 \mathrm{~m}$, while Scarabaeidae (Protaetia marmorata (Fabricius, 1792) and Staphylinidae (Quedius dilatatus (Fabricius, 1787)) were found with the highest abundance at the second and first forest layers $(7.8 \mathrm{~m})$. Cerambycidae (Leptura quadrifasciata Linnaeus, 1758) was predominantly caught at the most catchable height for all insects $(3.4 \mathrm{~m})$.

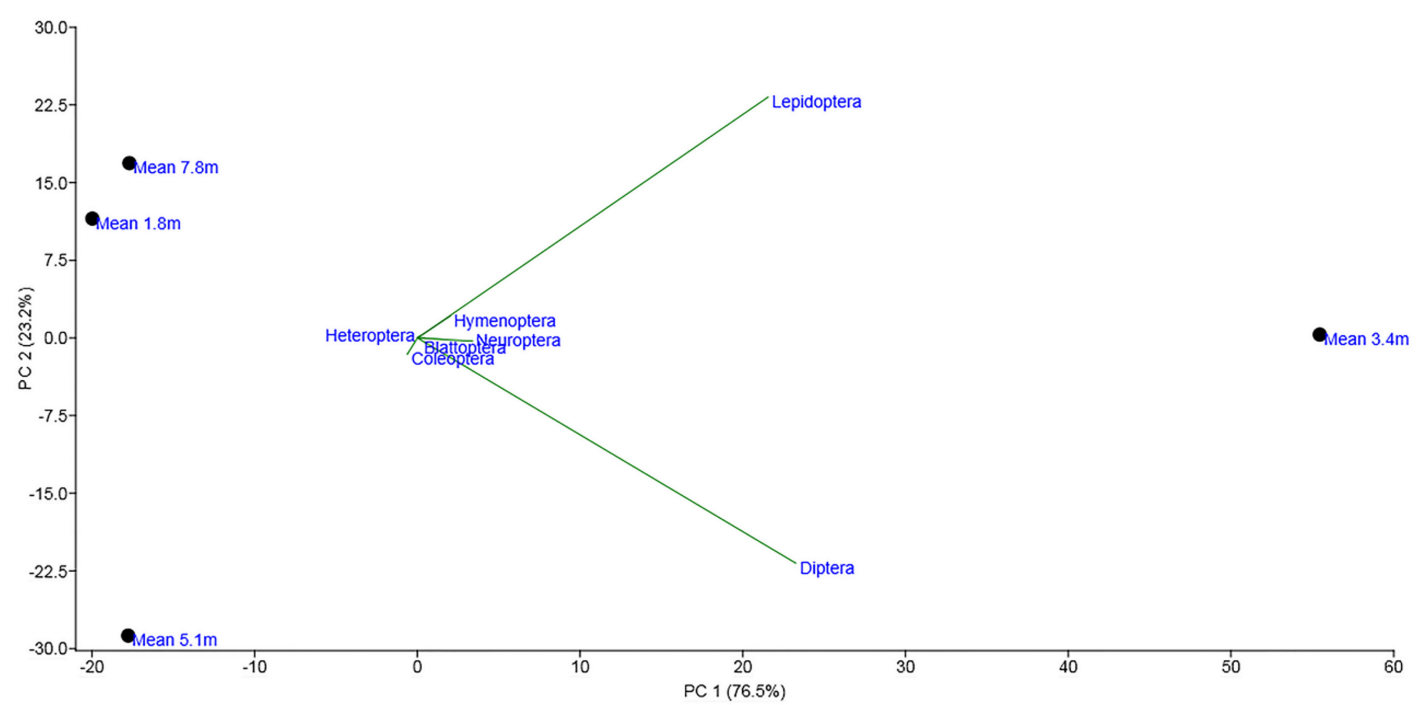

Fig. 11. Principal component analysis (PCA) ordination diagram indicating efficiency of traps located at different heights depending on the abundance of different insect orders caught in the study. «Mean» indicates that we used the averaged insect abundance from two sampling periods. Mean values of insect abundance per order were plotted onto PCA ordination diagram as supplementary en-vironmental variables. 


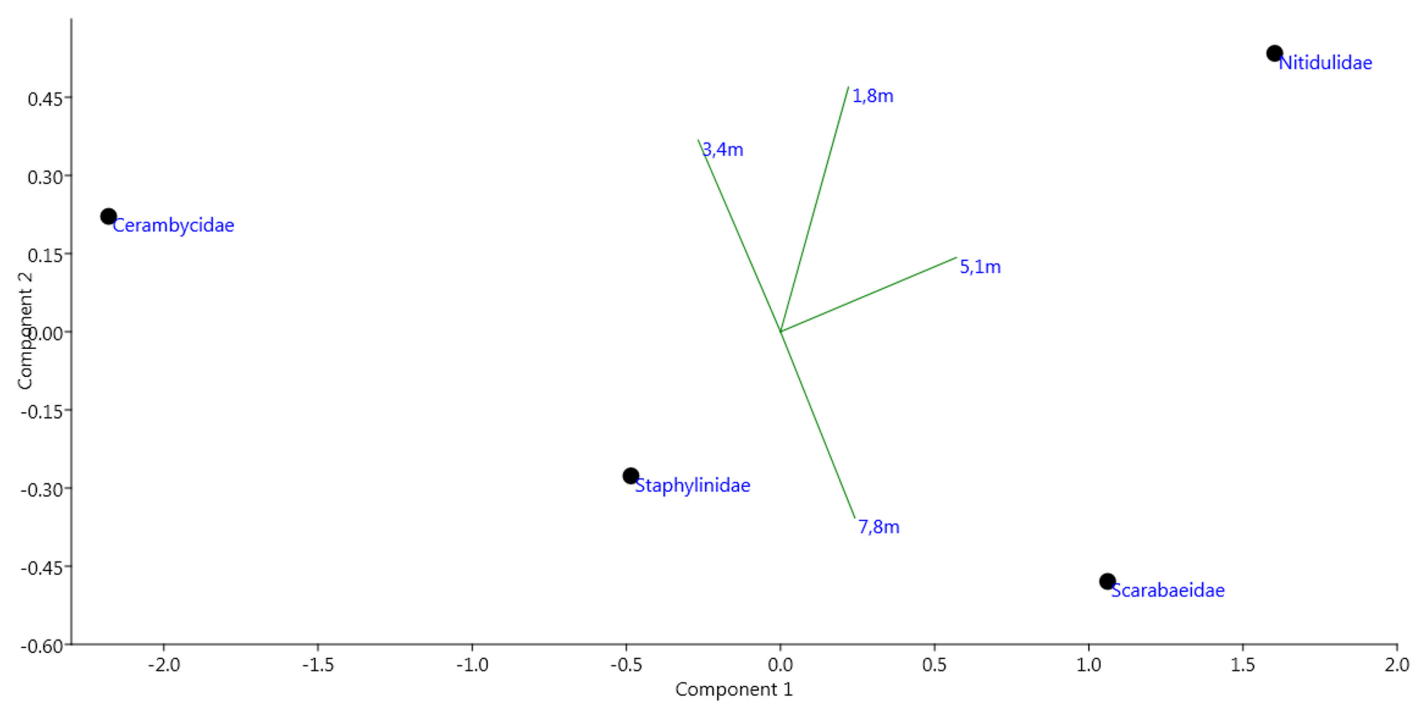

Fig. 12. Principal component analysis (PCA) ordination diagram indicating efficiency of traps located at different heights depending on abundance of Coleoptera families in the Mordovia State Nature Reserve (Russia). Mean values of insect abundance per order were plotted onto PCA ordination diagram as supplementary environmental variables.

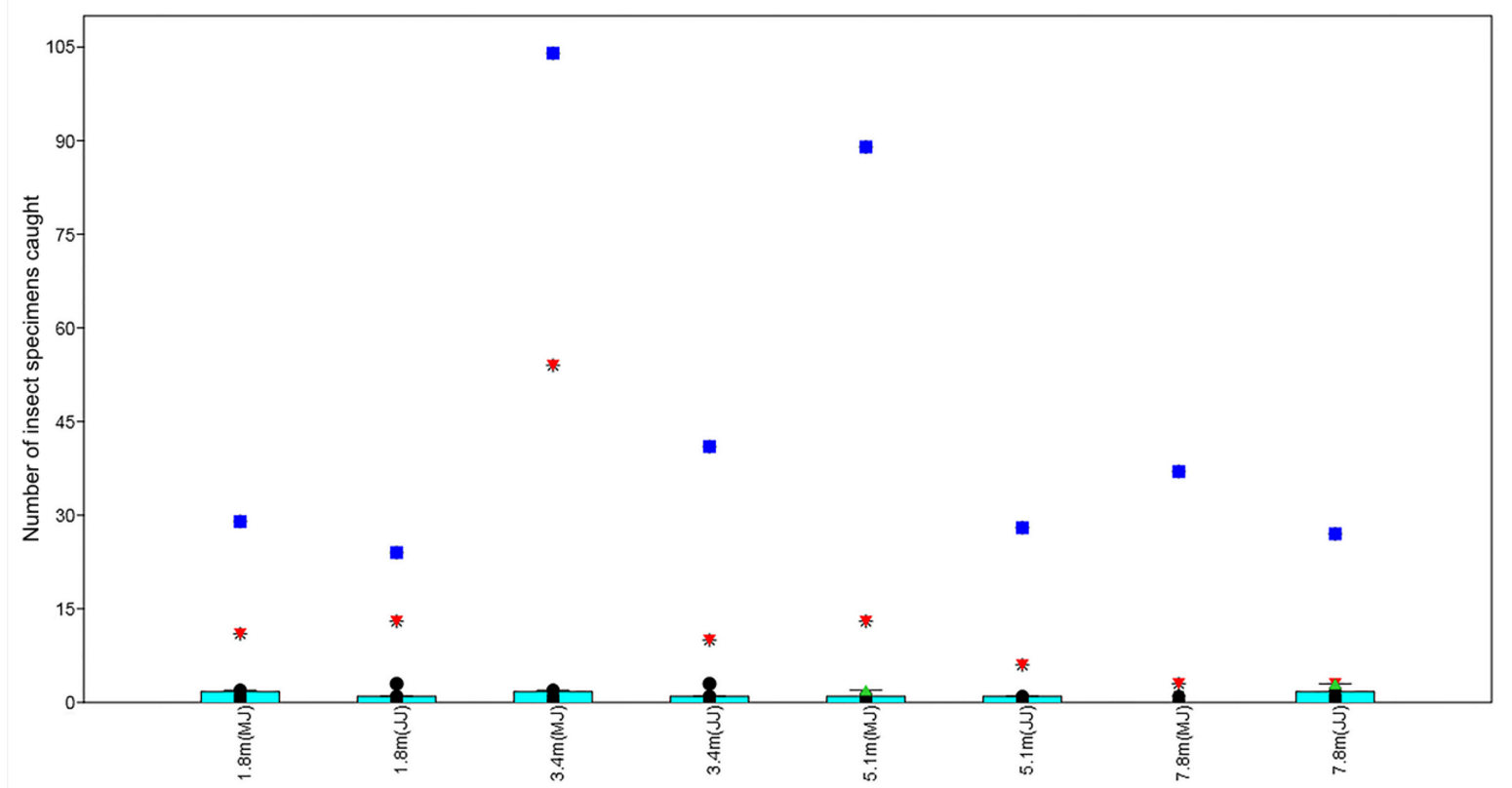

Fig. 13. The catch index of insects (Diptera families) obtained in two replications ( $1^{\text {st }}$ replication $-\mathrm{MS}, 2^{\text {nd }}$ replication $\left.-\mathrm{JJ}\right)$. The most abundant families are marked by colour symbols: blue square - Muscidae, red inverted triangle - Calliphoridae, green triangle - Drosophilidae. Y-axis indicates number of specimens caught; X-axis indicates different variants (heights) and replications (MJ, JJ).

Species from 16 Diptera families were identified in the study area (Fig. 13). At all four heights examined (i.e. $1.8 \mathrm{~m}, 3.4 \mathrm{~m}, 5.1 \mathrm{~m}, 7.8 \mathrm{~m}$ ), only three common (background) species were found in traps: Pollenia rudis Fabricius, 1794 (Calliphoridae), Phaonia pallida Fabricius, 1787 (Muscidae), and Helina impuncta Fallen, 1825 (Muscidae). It should be noted that the specimens' number of the most widespread species was approximately the same at heights of $1.8 \mathrm{~m}$ to $5.1 \mathrm{~m}$, while it begins to decline only at a height of $7.8 \mathrm{~m}$. Pollenia rudis larvae parasitise on earthworms (Rognes, 1987). Phaonia pallida larvae were hatching from rot- ting residues of plant origin and rotting protein substrates (Gaponov \& Panteleeva, 2017). Thus, two of the three mass species were not associated with wood as a place of larvae development. Their presence in traps was associated with imago activity. According to our observations, imagos of Phaonia pallida and Pollenia rudis have been usually caught in grass or on low shrubs. The high activity of these species in higher forest layers was an unexpected result. Another species that was caught at all heights is Helina impuncta Fallen, 1825 (Muscidae). The spatial arrangement of $H$. impuncta specimens was different than for the previous species: 
its smallest number of specimens was observed at a height of $1.8 \mathrm{~m}$. This is consistent with the typical $H$. impuncta behaviour because it is usually allocated at higher parts of tree trunks. We must note that our study has been conducted during limited time, in July. Therefore, many other Diptera species have not been caught in traps, although they could also be common species in certain seasons.

A few caught specimens do not allow making reasonable conclusions concerning the less widespread species. We believe that most of the Diptera specimens were caught occasionally in traps, although the presence of some of them was expected in trunk traps. For example, like other Odiniidae representatives, Neoalticomerus formosus Loew, 1844 was usually found only on trunks. And the larvae of Odiniidae species develop in dead wood and in flowing sap (Bree \& Ketelaar, 2018). As a rule, window gnats of the genus Sylvicola (Anisopodidae) inhabit tree trunks. They are caught in traps with beer (Dvořák, 2014; Dvořák et al., 2017). Finally, Metalimnobia quadrimaculata Linnaeus, 1760 (Limoniidae) larvae inhabit tree fungi (Krivosheina \& Krivosheina, 2010).

\section{Trapping rate dependence on the number of traps}

There is always a logical question: how many traps should be established during a study? The answer depends on the goals and objectives of the research. If the fauna of a particular biotope needs to be analysed, an understanding of its nature is needed. If this is a glade surrounded by forest, 1-2 traps can be enough. If this is the forest edge, then a dozen of traps may not be completely enough. On the other hand, to make an initial study of the fauna, one trap established at the correct time could be quite enough (Barlow et al., 2007; Ribeiro \& Freitas, 2012).

Some literature data indicate the need to establish a group of 3-5 traps to cover the entire biotope as much as possible (Uehara-Prado et al., 2007; Ribeiro \& Freitas, 2012). However, it has been reported that some traps attract a large number of individuals, while a neighbouring trap can hardly attract anyone. By combining three or more bait traps, the sampling becomes more uniform and it is more likely to reveal the biotope fauna (Freitas et al., 2014). Among other aspects, it is also important to understand, what distance is necessary to establish traps within a biotope. For example, Ribeiro et al. (2012) showed that the sampling is strongly affected by structure of landscape within about $200-\mathrm{m}$ radius around a trap. Seven traps with beer-based bait placed at a distance of 40-80 $\mathrm{m}$ from each other attracted sev- eral insect groups, among which representatives of Hymenoptera were present. However, other insect groups were caught irregularly and were not found in all traps (Hongayo et al., 2014).

We hypothesised that the distance between trees with established traps is an important factor influencing the catch index for insects. To test the hypothesis, we used NMDS analysis, where the distance between trees $(30 \mathrm{~m}, 40 \mathrm{~m}, 60 \mathrm{~m}, 90 \mathrm{~m}$, $110 \mathrm{~m}, 160 \mathrm{~m}$ ) was predictor, while the catch index per tree (Quercus robur, Tilia cordata, Acer platanoides, Fraxinus excelsior) formed environmental variables. Fig. 14 demonstrated no significant influence of the distance to the catch index of insects. In addition, SIMPER analysis (Table 4) did not confirm our assumption either. At the same time, we found that Quercus robur played a leading role in the catch index of insects (average dissimilarity contribution between tree species $-47.1 \%$ ). The lower values of average dissimilarity contribution were obtained for Tilia cordata (19.1\%), Fraxinus excelsior (16.0\%), and Acer platanoides (7.7\%). However, our results could be possibly explained by a larger number of Quercus robur trees involved in our research. Thus, we believe that the distance between trees with traps should be less than $300 \mathrm{~m}$ during field entomological studies within a single forest habitat with mixed structure. Experiments in California forests revealed that the relative abundance and faunistic similarity of insect assemblages in various traps varied highly in the trap types, while it depended little on the tree species. Family-level taxonomic wealth varied between different types of traps, tree species, and trap locations (Sussaenbach \& Fiedler, 1999).

Taking into account that Quercus robur trees characterised by the highest cumulative contribution in difference between distance groups, we assessed an influence of distance on the catch index of insects only on Quercus robur trees. We used NMDS analysis, where distances $(30 \mathrm{~m}, 40 \mathrm{~m}, 90 \mathrm{~m}, 110 \mathrm{~m})$ acted as predictors, while the numbers of insect specimens caught per Quercus robur tree were environmental variables. Fig. 15 demonstrates a clear distinguishing of polygons responsible for different distances. It indicates the considerable role of the distance between Quercus robur trees on the catch index values. On the other hand, it could be explained by the small sampling size. So, it should be confirmed in future by increasing the sampling size. Moreover, a SIMPER analysis of these data demonstrates relatively equal values of average dissimilarity contribution for all Quercus robur trees used in the study (Table 5). 


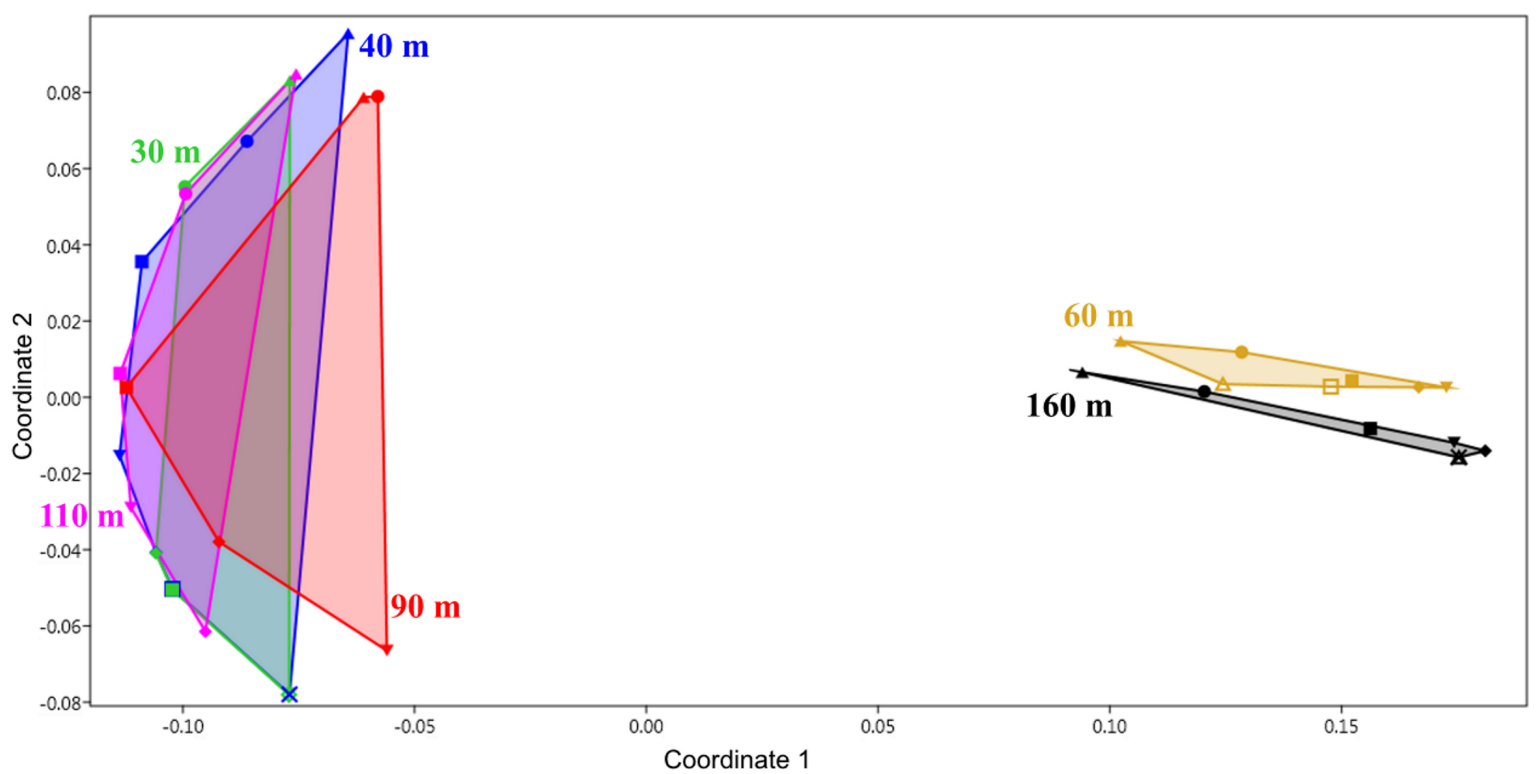

Fig. 14. Ordination diagram of the taxonomic structure of insects (order level) among the different distance up to the nearest tree (3D NMDS; $1+2$ plot axes; distance as explanatory variables).

Table 4. Similarity percentage analysis (SIMPER) of the abundance of insects caught on trees among the different distances up to the nearest tree

\begin{tabular}{|l|c|c|c|c|c|c|c|c|}
\hline Tree & Average dissimilarity & Contribution \% & Mean $40 \mathrm{~m}$ & Mean $60 \mathrm{~m}$ & Mean $160 \mathrm{~m}$ & Mean $30 \mathrm{~m}$ & Mean $110 \mathrm{~m}$ & Mean $90 \mathrm{~m}$ \\
\hline $\mathrm{Q}$ & 47.12 & 52.45 & 88.6 & 0 & 0 & 55.3 & 75.8 & 70.8 \\
\hline $\mathrm{T}$ & 19.07 & 21.23 & 0 & 89.1 & 0 & 0 & 0 & 0 \\
\hline $\mathrm{F}$ & 15.96 & 17.77 & 0 & 0 & 71.3 & 0 & 0 & 0 \\
\hline $\mathrm{A}$ & 7.682 & 8.552 & 0 & 0 & 0 & 0 & 0 & 57.4 \\
\hline
\end{tabular}

Note: $\mathrm{Q}$ - Quercus robur, $\mathrm{T}$ - Tilia cordata, $\mathrm{F}$ - Fraxinus excelsior, $\mathrm{A}$ - Acer platanoides.

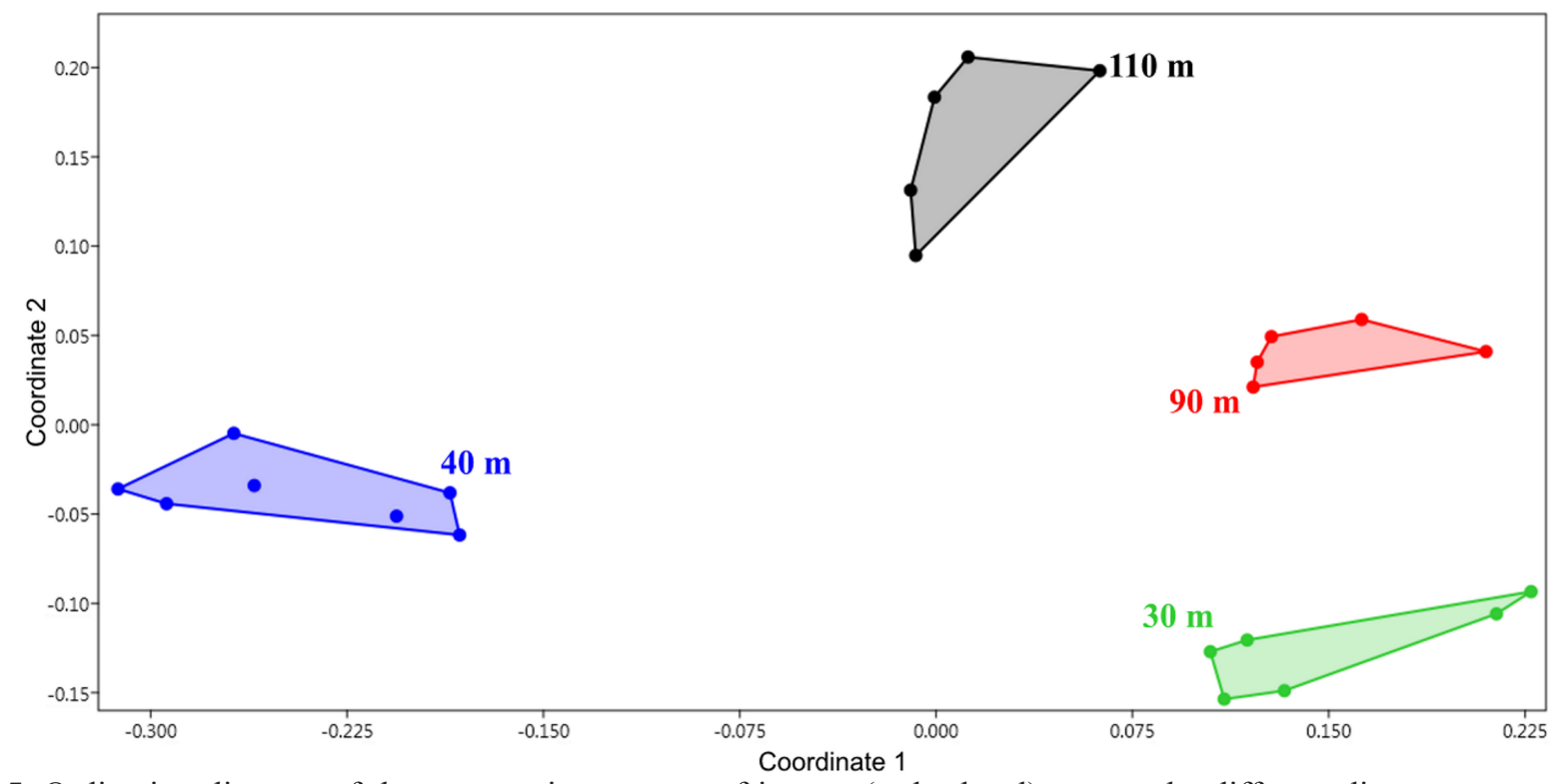

Fig. 15. Ordination diagram of the taxonomic structure of insects (order level) among the different distance up to nearest Quercus robur tree (3D NMDS; $1+2$ plot axes; distance as explanatory variables).

Table 5. Similarity percentage analysis (SIMPER) of the abundance of insects caught on Quercus robur trees among the different distances up to nearest tree

\begin{tabular}{|l|c|c|c|c|c|c|}
\hline \multicolumn{1}{|c|}{ Tree } & Average dissimilarity & Contribution $\%$ & Mean $40 \mathrm{~m}$ & Mean $30 \mathrm{~m}$ & Mean $110 \mathrm{~m}$ & Mean $90 \mathrm{~m}$ \\
\hline Q110 & 25.79 & 25.79 & 0 & 0 & 75.8 & 0 \\
\hline Q90 & 24.25 & 24.25 & 0 & 0 & 0 & 70.8 \\
\hline Q30 & 20.6 & 20.6 & 0 & 55.3 & 0 & 0 \\
\hline Q40 & 15.71 & 15.71 & 39.4 & 0 & 0 & 0 \\
\hline Q40 & 13.65 & 13.65 & 49.3 & 0 & 0 & 0 \\
\hline
\end{tabular}


Trapping rate dependence on exposure time

It is also important for a researcher to know the exposure time of a trap (i.e. a number of days to achieve sampling). It can depend on various reasons, both unbiased (weather, biotope, landscape remoteness) and subjective factors. The number of days for sampling may vary depending on the area of study site and the season. Ideally, the sampling sufficiency should be checked before attempting to conduct it in each sampling period. The sampling success varies in different biotopes. For example, in some semi-deciduous forests of Eastern Brazil, one trap can capture dozens of individuals per day at late dry season (Ribeiro \& Freitas 2012). This means that in this case, the exposure time should be slightly reduced. In our study, we also found that the exposure time affects the total amount of captured insects (Fig. 16).

Among all orders of captured insects, a direct correlation of the catch index and the exposure time was characteristic only for Lepidoptera, and only for Vespa crabro Linnaeus, 1758 from the order Hymenoptera. At the same time, the number of caught Diptera specimens was approximately similar between exposure times of 2 days and 10 days being thus slightly varied. This means that Diptera are immediately attracted to the bait and within 2-4 days their capture could be stopped. At the same time, the number of caught specimens of Lepidoptera and V. crabro increased over time.
Thus, the number of caught specimens increased with increasing exposure time. However, their number stabilised after 6-8 day. Within this time, all abundant taxonomic groups were already present in the sampling of individuals caught. But the increase in number of caught individuals occurred only due to Lepidoptera, which are difficult to be determined after getting wet in a trap. Therefore, we recommend establishing crown traps in the summer for no more than 6-8 days.

\section{Conclusions}

According to Golub et al. (2012), the described type of trap can be classified as «Trap with bait in a container». Many insects have receptors perceiving carbohydrates. It explains why they are attracted to beer-based fermented baits with added sugar and other sugar-containing baits. According to many recent studies (Foster, 1995; Sanchez-Gracia et al., 2011; Engsontia et al., 2014; Xu, 2019), insects have the ability to absorb sugar playing a critical role in the insect life as valuable energy and food resource. Sugar perception is always used by insects to evaluate the nutritional value of feed. Sugar and its decomposition products form the primary stimulating signal for insect nutrition (Kent \& Robertson, 2009). The use of crown traps with a bait on the basis of sugars and products of their fermentation is explained precisely by this insect perception.

$$
10 \text { day }
$$
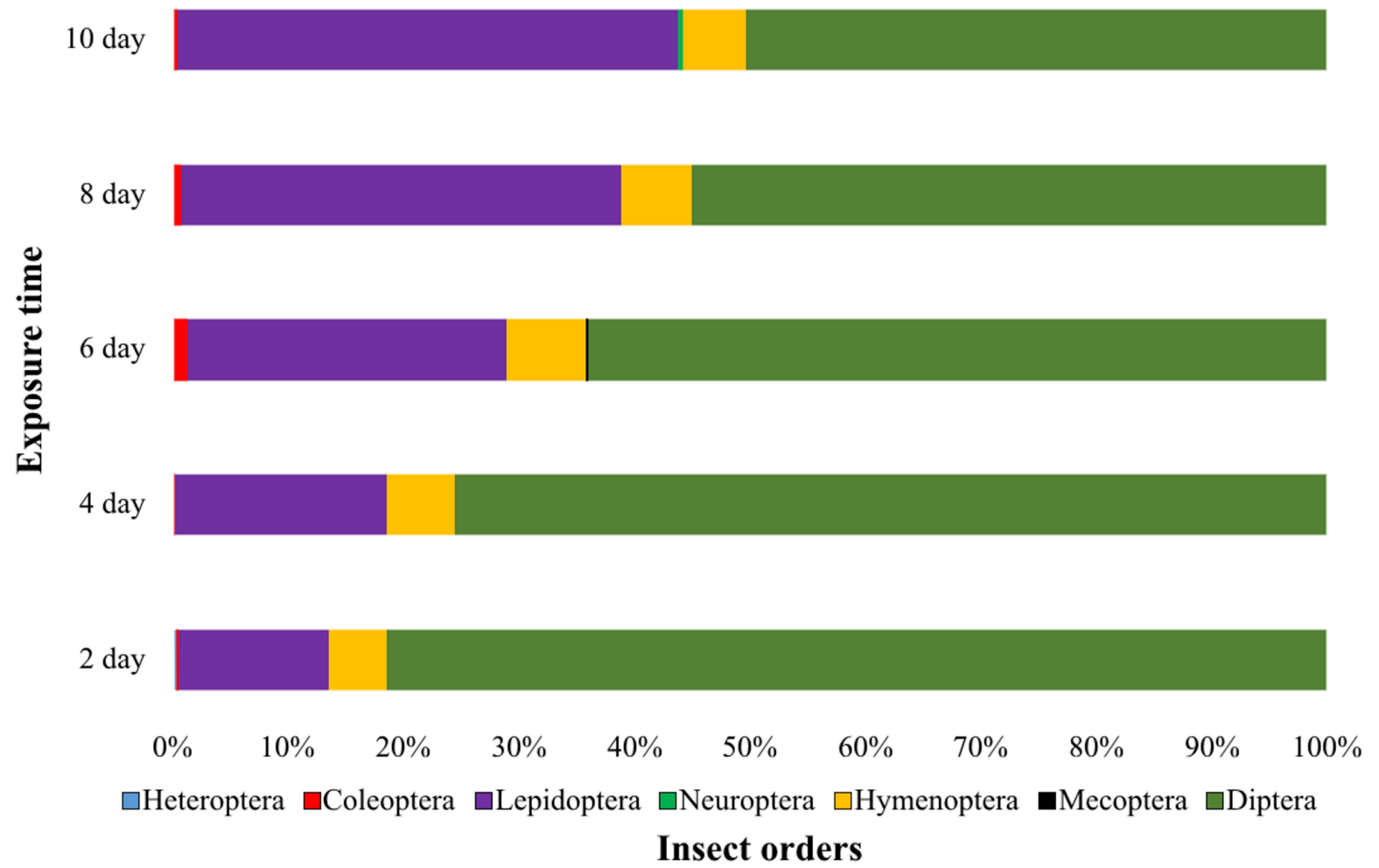

Fig. 16. The taxonomic composition (order level) and the ratio of the number of collected insect specimens (OY axis) depending on the exposure time (OX axis). 
Crown traps are an effective tool to study the insect fauna of the upper forest layers. Crowns of forest stand are usually less studied than the ground and herb layers (Basset, 2001). The choice of a specific trap location should not cause doubts. But it is better to inspect the surroundings and establish traps at a distance of at least $10 \mathrm{~m}$ from sap-producing trees. In temperate regions of the forest natural zone, these species are Quercus, Acer, Fraxinus, Ulmus, and Tilia. On the other hand, we have repeatedly established traps in solid Pinus sylvestris forests, mixed forests with Pinus sylvestris dominance. As a result, we obtained appropriate results on the species composition in these biotopes. However, it should be noted that in such forests the insect fauna attracted to traps was depleted in comparison with broadleaved forests (our unpublished data). In large forest areas, sites with sparsely located trees are more favourable for establishing of traps. Traps should be placed on the branches, along glades and clearings, at the edge of the forest. Traps should be suspended to living tree trunks, located on thick branches (with a diameter of at least $5 \mathrm{~cm}$ ) to limit the wind effects.

This trap type can be used to study the vertical insect distribution in forest systems. Such traps are easy to use, unlike some other proposed methods (Su \& Woods, 2001). On the other hand, they could complement other methods to obtain better results. According to recently published research results (Ruchin et al., 2019; Ruchin \& Khapugin, 2019), only 13 localities were indicated in the Republic of Mordovia where Protaetia fieberi (Kraatz, 1880) was registered in 2013-2018. In this study, manual collection and partially window traps were mainly used. In 2019, 37 locations of this species (occurrence of $37.4 \%$ ) from 99 crown traps at different study sites were identified. Thus, Protaetia fieberi is probably much more common. Until 2017, there was little information about Leptura thoracica Creutzer, 1799. This species was considered as very rare (Ruchin \& Egorov, 2018c). However, 11 new localities of this species were immediately registered using crown traps only in 2018 (Ruchin \& Egorov, 2018a,b). This confirms the earlier conclusions that the insect fauna in the tree crowns can differ significantly from the fauna of the ground and herb layers (Tanabe, 2002; Wermelinger et al., 2007; Roche et al., 2015; Weiss et al., 2019).

From year to year, the catch index of the species can vary widely at the same locality. Therefore, we believe, it is necessary to repeat the experiment for two years to roughly determine the fauna in a biotope. Our 2018 and 2019 experiments in the Mordovia State Nature Reserve confirm this assumption. Different results on the Coleoptera fauna were obtained by establishing traps on the same places in a similar season. For example, a significant amount of Gnorimus variabilis (Linnaeus, 1758) was caught in 2018 (Ruchin \& Egorov, 2018a), whereas this species was represented by single specimens in 2019 at the same time on the same place traps. Similar data were obtained by Allemand \& Aberlenc (1991) who caught two rare Coleoptera species on one place in different years in different number. The recent studies of Leptura thoracica Creutzer, 1799 have demonstrated interesting results. Danilevsky et al. (2019) found that in European Russia this species has a pronounced sexual dimorphism in the colour of the elytra. These data were obtained exactly by using crown traps. Also, these traps can be used to study the seasonal activity cycles of some insects, i.e. in phenological studies. It especially concerns some species and families in the orders Coleoptera and Diptera.

According to the results of catches, the insect species composition revealed by crown traps iffered from those caught using other approaches. Therefore, we recommend using crown traps to make a comprehensive examination where a variety of methods complement each other. Being used correctly, such traps can be an effective toolto study the biodiversity and/or biology and ecology of threatened insect species (Laaksonen et al., 2006). For example, there was a lack of data on a very rare saproxyl species Protaetia speciosissima (Scopoli, 1786), which was found mainly in broadleaf, less often in mixed forests, and its localities in the Republic of Mordovia, Russia (Ruchin \& Egorov, 2017). However, the use of crown traps made it possible to identify several new localities and the question arose about the conservation of its habitats.

\section{Recommendations}

All the recommendations presented above could be summarised as follows: 1) it is very important to determine the sampling size, number of established traps, as well as the general efforts for sampling; 2) a correct taxonomic treatment is needed to understand the local insect fauna; 3 ) it is necessary to know the local insect flora, especially in forests with tree species forming their basic conditions; 4) it is necessary to determine the research objective (study of the entire fauna in the study area or the fauna of individual taxonomic groups), as it determines the choice of study site(s), and trap height; 5) it is better to use sugar and honey in a bait; 6) for better capture, it is necessary to correctly determine the composition of the bait mixture, the height and location of the traps; 7) the exposure time should not exceed (seven or) eight days in the summer months. 


\section{References}

Ausden M., Drake M. 2006. Invertebrates. In: W.J. Sutherland (Ed.): Ecological Census Techniques, a handbook. $2^{\text {nd }}$ edition. Cambridge: Cambridge University Press. P. 214-249.

Alekseev V.I., Shapoval A.P. 2011. Coleoptera caught by a light trap on the Curonian Spit: 2009 data. Proceedings of the Mordovia State Nature Reserve 9: 4-19. [In Russian]

Alexeev S.C., Aleksanov V.V. 2017. Pitfall trap construction affects the efficacy of ground beetle counts. Zoologicheskii Zhurnal 96(3): 295-304. DOI: 10.7868/S00 44513417010032

Allemand R., Aberlenc H.-P. 1991. Une méthode efficace d'echantillonage de l'entomofaune des frondaisons: le piège attractif aérien. Bulletin de la Société Entomologique Suisse 64: 293-305.

Ali K., Rapuzzi P., Ihsan S. 2015. Contribution to the knowledge of the longhorn beetles (Coleoptera, Cerambycidae) of the Syrian Coastal Region. Biodiversity Journal 6(2): 637-662.

Bardiani M., Tini M., Carpaneto G.M., Audisio P., Bussola E., Campanaro A., Cini A., Maurizi E., Mason F., Peverieri G.S., Roversi P.F., Toni I., Chiari S. 2017. Effects of trap baits and height on stag beetle and lower chafer monitoring: ecological and conservation implications. Journal of Insect Conservation 21(1): 157-168. DOI: 10.1007/s10841-017-9965-3

Barlow J., Overal W.L., Araujo I.S., Gardner T.A., Peres C.A. 2007. The value of primary, secondary and plantation forests for fruitfeeding butterflies in the Brazilian Amazon. Journal of Applied Ecology 44(5): 1001-1012. DOI: 10.1111/j.13652664.2007.01347.x

Basset Y. 2001. Invertebrates in the canopy of tropical rain forests. How much do we really know? Plant Ecology 153(1-2): 87-107. DOI: 10.1023/A:1017581406101

Benediktov A.A., Belyaev O.A. 2019. New data on acoustic signals of Stauroderus scalaris (Orthoptera: Acrididae) from different local populations with a note about its parasite from the genus Blaesoxipha (Diptera: Sarcophagidae). Nature Conservation Research 4(1): 22-28. DOI: 10.24189/ncr.2019.001 [In Russian]

Bharathi T.E., Sathiyanandam V.K.R., David P.M.M. 2004. Attractiveness of some food baits to the melon fruit fly, Bactrocera cucurbitae (Coquillett) (Diptera: Tephritidae). International Journal of Tropical Insect Science 24(2): 125-134. DOI: 10.1079/ IJT200412

Bouget C., Brustel H., Brin A., Noblecourt T. 2008. Sampling saproxylic beetles with window flight traps: methodological insights. Revue d'Ecologie, Terre et Vie, Société nationale de protection de la nature Suppt.10: 21-32.

Bree E., Ketelaar R. 2018. Neoalticomerus formosus new for the fauna of the Netherlands (Diptera: Odiniidae). Entomologische Berichten 78(6): 226-228.
Bulgakova M.A., Pyatina E.V. 2019. The role of ungulates in soil zoocoenosis development of the steppe zone of the Urals. Nature Conservation Research 4(Supp1.2): 94-97. DOI: 10.24189/ncr.2019.037

Carrel J.E. 2002. A novel aerial-interception trap for arthropod sampling. The Florida Entomologist 85: 656657. DOI: 10.1653/0015-4040(2002)085[0656:AN AITF]2.0.CO;2

Daily G.C., Ehrlich P.R. 1995. Preservation of biodiversity in small rainforest patches: rapid evaluations using butterfly trapping. Biodiversity and Conservation 4(1): 35-55. DOI: 10.1007/BF00115313

Danilevsky M.L., Ruchin A.B., Egorov L.V. 2019. Mass collection of two rare Longicorn-species (Coleoptera, Cerambycidae) in Central Russia. Humanity Space 8(9): 1179-1183.

Demichelis S., Manino A., Minuto G., Mariotti M., Porporato M. 2014. Social wasp trapping in North West Italy: comparison of different bait-traps and first detection of Vespa velutina. Bulletin of Insectology 67(2): 307-317.

Devries P.J., Walla T.R. 2001. Species diversity and community structure in neotropical fruit-feeding butterflies. Biological Journal of the Linnean Society 74(1): 1-15. DOI: 10.1006/bij1.2001.0571

Dobony C.A., Edwards J.W. 2001. A new flight-interception trap for arthropod sampling. Entomology News 112: $217-220$.

Dodds K.J. 2014. Effects of trap height on captures of arboreal insects in pine stands of northeastern United States of America. Canadian Entomologist 146(1): 80-89. DOI: $10.4039 /$ tce.2013.57

Duelli P., Moretti M., Tonolla D., Barbalat S. 2006. Scented traps yield two large lacewing species (Neuroptera, Chrysopidae) new to Switzerland. Bulletin de la Société Entomologique Suisse 79: 25-28. DOI: $10.5169 /$ seals-402909

Dumbrell A.J., Hill J.K. 2005. Impacts of selective logging on canopy and ground assemblages of tropical forest butterflies: implications for sampling. Biological Conservation 125(1): 123-131. DOI: 10.1016/j.biocon.2005.02.016

Dvořák L. 2007. Social wasps (Hymenoptera: Vespidae) trapped with beer in European forest ecosystems. Acta Musei Moraviae, Scientiae Biologicae 98: 181-204.

Dvořák L. 2014. Window gnats (Diptera: Anisopodidae) from beer traps in the vicinity of Mariánské lázně with the first records of Sylvicola zetterstedti (Edwards, 1923) from the Czech Republic. Bulletin de la Société Entomologique Suisse 87: 41-48.

Dvořák L., Haenni J.-P., Máca J., Mariychuk R., Oboňa J. 2017. Some insects (Dermaptera, Diptera, Mecoptera) from beer traps in Uzhhorod City (Ukraine). Folia Oecologica 9(2): 11-17.

Dvořáková K. 2008. Heleomyzidae and Lauxaniidae (Diptera, Brachycera, Acalyptrata) trapped in the Czech Republic with syrup and fermented fruit. Linzer Biologische Beiträge 40(1): 507-515. 
Egorov L.V., Ivanov A.V. 2018. Beetles (Insecta, Coleoptera), collected by fermenting bait crown traps in Chuvashia. Proceedings of the Mordovia State $\mathrm{Na}$ ture Reserve 21: 191-204. [In Russian]

Egorov L.V., Semishin G.B. 2016. The coleopterans collected using window traps in the Mordovia State Nature Reserve. Report 1. Proceedings of the Mordovia State Nature Reserve 17: 70-78. [In Russian]

El-Sayed A.M., Heppelthwaite V.J., Manning L.M., Gibb A.R., Suckling D.M. 2005. Volatile Constituents of Fermented Sugar Baits and Their Attraction to Lepidopteran Species. Journal of Agricultural and Food Chemistry 53(4): 953-958. DOI: 10.1021/jf048521j

Engsontia P., Sangket U., Chotigeat W., Satasook C. 2014. Molecular Evolution of the Odorant and Gustatory Receptor Genes in Lepidopteran Insects: Implications for Their Adaptation and Speciation. Journal of Molecular Evolution 79(1-2): 21-39. DOI: $10.1007 / \mathrm{s} 00239-014-9633-0$

Gaponov S.P., Panteleeva N.Yu. 2017. New data of saprobiont larval feeding habits of Brachycera (Diptera) in the Middle Podonye. III. Superfamilies Muscoidea and Oestroidea. Proceedings of Voronezh State University Series: Chemistry. Biology. Pharmacy 1: 49-56. [In Russian]

Golub V.B., Tsurikov M.N., Prokin A.A. 2012. Insect collections: collection, processing and storage of material. Moscow: KMK Scientific Press Ltd. 339 p. [In Russian]

Grøtan V., Lande R., Engen S., Sæther B.-E., Devries P.J. 2012. Seasonal cycles of species diversity and similarity in a tropical butterfly community. Journal of Animal Ecology 81(3): 714-723. DOI: 10.1111/j.1365-2656.2011.01950.x

Guarnieri F.G. 2009. A survey of longhorned beetles (Coleoptera: Cerambycidae) from Paw Paw, Morgan County, West Virginia. Maryland Entomologist 5(1): 11-22.

Foster W.A. 1995. Mosquito sugar feeding and reproductive energetics. Annual Review of Entomology 40: 443-474. DOI: 10.1146/annurev. en.40.010195.002303

Freitas A.V.L., Iserhard C.A., Santos J.P., Carreira J.Y.O., Ribeiro D.B., Melo D.H.A., Rosa A.H.B., MariniFilho O.J., Accacio G.M., Uehara-Prado M. 2014. Studies with butterfly bait traps: an overview. Revista Colombiana de Entomología 40(2): 203-212.

Hammer Ø., Harper D.A.T., Ryan P.D. 2001. PAST: Paleontological statistics software package for education and data analysis. Palaeontologia Electronica 4(1): 9 p.

Hongayo M.C., Balahay C.L., Cajes M.E.P., Sumampong O. 2014. Fermented beer-based bait attracted insects taxa in Songculan Lagoon, Songculan, Dauis, and Bohol, Philippines. Scientific Journal of Biological Sciences 3(1): 6-10. DOI: 10.14196/sjbs.v3i1.1125

Jackman J.A., Nelson C.R. 1995. Diversity and phenology of tumbling flower beetles (Coleoptera: Mordellidae) captured in a Malaise trap. Entomological News 106(3): 97-107.
Jalas I. 1960. Eine leichtgebaute, leichttransportable Lichtreuse zum Fangen von Schmetterlingen. Annales Entomologicae Fennicae 26: 44-50.

Jakubikova L., Kadlec T. 2015. Butterfly bait traps versus zigzag walks: What is the better way to monitor common and threatened butterflies in non-tropical regions? Journal of Insect Conservation 19(5): 911-919. DOI: 10.1007/s10841-015-9809-y

Jocque M., Teofilova T.M., Kodzhabashev N.D. 2016. Light trapping as a valuable rapid assessment method for ground beetles (Carabidae) in a Bulgarian Wetland. Acta Zoologica Bulgarica 68(4): 529-539.

Kazantsev S.V., Egorov L.V., Ruchin A.B. 2019. Discovery of Lopheros lineatus (Gorham, 1883) (Coleoptera, Lycidae) in Mordovia, Central Russia. Entomological Review 99(5): 656-659. DOI: 10.1134/ S0013873819050099

Kent L., Robertson H. 2009. Evolution of the sugar receptors in insects. BMC Evolutionary Biology 9: 41. DOI: $10.1186 / 1471-2148-9-41$

Khapugin A.A. 2019. Benefits from visualization of environmental factor gradi-ents: a case study in a protected area in central Russia. Revista Chapingo Serie Ciencias Forestales y del Ambiente 25(3): 383-398. DOI: 10.5154/r.rchscfa.2019.01.004

Khapugin A.A., Ruchin A.B. 2019. Red Data Book of vascular plants of the Mordovia State Nature Reserve, a protected area in European Russia. Wulfenia 26: 53-71.

Korb S.K. 2018. Automatic autonomous light traps and their usage for the quantitative accountingon example of hawkmoths of Kyrgyzstan (Lepidoptera: Sphingidae). Nature Conservation Research 3(3): 80-85. DOI: 10.24189/ncr.2018.017

Krivosheina M.G., Krivosheina N.P. 2010. New data on morphology and ecology of Limoniid fly larvae of the genus Metalimnobia (Diptera, Limoniidae) developed in fungal substrates. Entomological Review 90(6): 764-782. DOI: 10.1134/S0013873810060138

Krivosheina N.P., Krivosheina M.G. 2019. Saproxylic Diptera (Insecta) of the Lazovsky State Nature Reserve (Russia). Nature Conservation Research 4(3): 78-92. DOI: 10.24189/ncr.2019.052

Laaksonen J., Laaksonen T., Itämies J., Rytkönen S., Välimäki P. 2006. A new efficient bait-trap model for Lepidoptera surveys - the «Oulu» model. Entomologica Fennica 17(2): 153-160. DOI: 10.33338/ ef.84301

Lucid M.K., Ehlers S., Robinson L., Cushman S.A. 2018. Beer, brains, and brawn as tools to describe terrestrial gastropod species richness on a montane landscape. Ecosphere 9(12): e02535. DOI: 10.1002/ ecs 2.2535

Makarkin V.N., Ruchin A.B. 2019. New data on Neuroptera and Raphidioptera of Mordovia (Russia). Caucasian Entomological Bulletin 15(1): 147-157. DOI: 10.23885/181433262019151-147157 [In Russian]

Manko P., Demková L., Kohútová M., Oboňa J. 2018. Efficiency of traps in collecting selected Diptera families 
according to the used bait: comparison of baits and mixtures in a field experiment. European Journal of Ecology 4(2): 92-99. DOI: 10.2478/eje-2018-0016

MacRae T.C. 2015. Beetle Collecting 101: Fermenting bait traps for collecting longhorned beetles. Available from: https://beetlesinthebush.wordpress. com/2015/12/28/beetle-collecting-101-fermentingbait-traps-for-collecting-longhorned-beetles/

MacRae T.C., Rice M.E. 2007. Distributional and biological observations on North American Cerambycidae (Coleoptera). The Coleopterists Bulletin 61(2): 227-263.

McCravy K.W. 2017. An analysis of Malaise-trap effectiveness in assessing robber fly (Diptera: Asilidae) species richness. Northeastern Naturalist 24(1): 15-24. DOI: 10.1656/045.024.0102

McCravy K.W. 2018. A review of sampling and monitoring methods for beneficial arthropods in agroecosystems. Insects 9(4): 170. DOI: 10.3390/insects 9040170

McCravy K.W., Geroff R.K., Gibbs J. 2016. Malaise trap sampling efficiency for bees (Hymenoptera: Apoidea) in a restored tallgrass prairie. Florida Entomologist 99(2): 321-323. DOI: 10.1653/024.099.0230

Padilha A.C., Arioli C.J., Boff M.I.C., Rosa J.M., Botton M. 2018. Traps and baits for luring Grapholita molesta (Busck) adults in mating disruption-treated apple orchards. Neotropical Entomology 47(1): 152-159. DOI: $10.1007 / \mathrm{s} 13744-017-0517-z$

Pettersson L.B., Franzén M. 2008. Comparing winebased and beer-based baits for moth trapping: a field experiment. Entomologisk Tidskrift 129(3): 129-134.

Procházka J., Cizek L., Schlaghamerský J. 2018. Vertical stratification of scolytine beetles in temperate forests. Insect Conservation and Diversity 11(6): 534-544. DOI: 10.1111/icad.12301

Redolfi De Zan L., Bardiani M., Antonini G., Campanaro A., Chiari S., Mancini E., Maura M., Sabatelli S., Solano E., Zauli A., Sabbatini Peverieri G., Roversi P.F. 2017. Guidelines for the monitoring of Cerambyx cerdo. Nature Conservation 20: 129-164. DOI: 10.3897/natureconservation.20.12703

Ribeiro D.B., Batista R., Prado P.I., Brown Jr.K.S., Freitas A.V.L. 2012. The importance of small scales to the fruit-feeding butterfly assemblages in a fragmented landscape. Biodiversity and Conservation 21(3): 811-827. DOI: 10.1007/s10531-011-0222-x

Ribeiro D.B., Freitas A.V.L. 2010. Differences in thermal responses in a fragmented landscape: temperature affects the sampling of diurnal, but not nocturnal fruit-feeding Lepidoptera. Journal of Research on the Lepidoptera 42: 1-4.

Ribeiro, D.B., Freitas A.V.L. 2012. The effect of reducedimpact logging on fruit-feeding butterflies in Central Amazon, Brazil. Journal of Insect Conservation 16(5): 733-744. DOI: 10.1007/s10841-012-9458-3

Roche K.N., Piorkowski J.M., Sanyaolu R.A., Cordeiro N.J. 2015. Vertical distribution of fruit-feeding but- terflies with evidence of sex-specific differences in a Tanzanian forest. African Journal Ecology 53(4): 480-486. DOI: 10.1111/aje. 12234

Rognes K. 1987. The taxonomy of the Pollenia rudis species-group in the Holarctic Region (Diptera: Calliphoridae). Systematic Entomology 12(4): 475-502. DOI: 10.1111/j.1365-3113.1987.tb00219.x

Rozhnov V.V., Lavrinenko I.A., Razzhivin V.Yu., Makarova O.L., Lavrinenko O.V., Anufriev V.V., Babenko A.B., Bizin M.S., Glazov P.M., Goryachkin S.V., Kolesnikova A.A., Matveyeva N.V., Pestov S.V., Petrovskii V.V., Pokrovskaya O.B., Tanasevich A.V., Tatarinov A.G. 2019. Biodiversity revision of a large arctic region as a basis for its monitoring and protection under conditions of active economic development (Nenetsky Autonomous Okrug, Russia). Nature Conservation Research 4(2): 1-28. DOI: $10.24189 /$ ncr.2019.015

Ruchin A.B., Egorov L.V. 2017. Overview of insect species included in the Red Data Book of Russian Federation in the Mordovia State Nature Reserve. $\mathrm{Na}$ ture Conservation Research 2(Suppl. 1): 2-9. DOI: 10.24189/ncr.2017.016

Ruchin A.B., Egorov L.V. 2018a. Beetles (Insecta, Coleoptera), collected using fermental crown trap in the Republic of Mordovia. Report 1. Mordovia State Nature Reserve. Scientific Proceedings of the State Nature Reserve «Prisursky» 33: 209-215. [In Russian]

Ruchin A.B., Egorov L.V. 2018b. Beetles (Insecta, Coleoptera), collected using fermental crown trap in the Republic of Mordovia. Report 2. National Park «Smolny». Scientific Proceedings of the State Nature Reserve «Prisursky» 33: 215-218. [In Russian]

Ruchin A.B., Egorov L.V. 2018c. Fauna of longicorn beetles (Coleoptera: Cerambycidae) of Mordovia. Russian Entomological Journal 27(2): 161-177. DOI: 10.15298/rusentj.27.2.07

Ruchin A.B., Khapugin A.A. 2019. Red Data Book Invertebrates in a Protected Area of European Russia. Acta Zoologica Academiae Scientiarum Hungaricae 65(4): 349-370. DOI: 10.17109/AZH.65.4.349.2019

Ruchin A.B., Mikhailenko A.P. 2018. Fauna of mantids and orthopterans (Insecta: Mantodea, Orthoptera) of the Mordovia State Nature Reserve, Russia. Biodiversitas 19(4): 1194-1206. DOI: 10.13057/biodiv/ d190403

Ruchin A.B., Alekseev S.K., Khapugin A.A. 2019. Postfire fauna of carabid beetles (Coleoptera, Carabidae) in forests of the Mordovia State Nature Reserve (Russia). Nature Conservation Research 4(Suppl.1): 11-20. DOI: 10.24189/ncr.2019.009

Sanchez-Gracia A., Vieira F.G., Almeida F.C., Rozas J. 2011. Comparative genomics of the major chemosensory gene families in Arthropods. In: Encyclopedia of Life Sciences. Chichester: John Wiley \& Sons, Ltd. P. 1-12. DOI: 10.1002/9780470015902.a0022848

Schmeelk T.C., Millar J.G., Hanks L.M. 2016. Influence of trap height and bait type on abundance and species diversity of cerambycid beetles captured in forests of 
East-Central Illinois. Journal of Economic Entomology 109(4): 1750-1757. DOI: 10.1093/jee/tow 102

Skvarla M.J., Dowling A.P.G. 2017. A comparison of trapping techniques (Coleoptera: Carabidae, Buprestidae, Cerambycidae, and Curculionoidea excluding Scolytinae). Journal of Insect Science 17(1): 7. DOI: 10.1093/jisesa/iew098

Shapovalov A.M. 2012. Longicorn beetles (Coleoptera, Cerambycidae) of the Orenburg region: fauna, distribution, bionomy. Orenburg: Printing House «Express Printing». 224 p. [In Russian]

Sheehan T.N., Ulyshen M.D., Horn S., Hoebeke E.R. 2019. Vertical and horizontal distribution of bark and woodboring beetles by feeding guild: is there an optimal trap location for detection? Journal of Pest Science 92(1): 327-341. DOI: 10.1007/s10340-018-1026-5

Sorvari J. 2013. Social wasp (Hymenoptera: Vespidae) beer trapping in Finland 2008-2012: a German surprise. Entomologica Fennica 24(3): 156-164. DOI: $10.33338 /$ ef. 8983

Sorvari J. 2019. Yellow does not improve the efficiency of traps for capturing wasps of the genera Vespula and Dolichovespula (Hymenoptera: Vespidae). European Journal of Entomology 116: 240-243. DOI: 10.14411/eje.2019.027

Sourakov A., Emmel T.C. 1995. Bait trapping for butterflies in Kenya. Tropical Lepidoptera 6: 1-2.

Su J.C., Woods S.A. 2001. Importance of sampling along a vertical gradient to compare the insect fauna in managed forests. Environmental Entomology 30(2): 400-408. DOI: 10.1603/0046-225X-30.2.400

Sussaenbach D., Fiedler K. 1999. Noctucid moths attracted to fruit bait: testing models and methods of estimating species diversity. Nota Lepidopterologica 22(2): 115-145.

Tanabe S.I. 2002. Between-forest variation in vertical stratification of drosophilid populations. Ecological Entomology 27(6): 720-731. DOI: 10.1046/j.13652311.2002.00469.x

Tomaszewska W., Egorov L.V., Ruchin A.B., Vlasov D.V. 2018. First record of Clemmus troglodytes (Coleoptera: Coccinelloidea, Anamorphidae) for the fauna of Russia. Nature Conservation Research 3(3): 103-105. DOI: 10.24189/ncr.2018.016

Quinto J., Marcos-García M.Á., Brustel H., Galante E., Micó E. 2013. Effectiveness of three sampling methods to survey saproxylic beetle assemblages in Mediterranean woodland. Journal of Insect Conservation 17(4): 765-776. DOI: 10.1007/s10841-013-9559-7

Uehara-Prado M., Freitas A.V.L. 2009. The effect of rainforest fragmentation on species diversity and mimicry ring composition of ithomiine butterflies. Insect Conservation and Diversity 2(1): 23-28. DOI: $10.1111 /$ j.1752-4598.2008.00025.X

Uehara-Prado M., Brown Jr.K.S., Freitas A.V.L. 2007. Species richness, composition and abundance of fruitfeeding butterflies in the Brazilian Atlantic Forest: comparison between a fragmented and a continuous landscape. Global Ecology and Bio- geography 16(1): 43-54. DOI: 10.1111/j.14668238.2006.00267.x

Ulyshen M.D. 2011. Arthropod vertical stratification in temperate deciduous forests: Implications for conservation-oriented management. Forest Ecology and Management 261(9): 1479-1489. DOI: 10.1016/j.foreco.2011.01.033

Utrio P., Eriksson K. 1977. Volatile fermentation products as attractants for Macrolepidoptera. Annales Zoologici Fennici 14(2): 98-104.

Valdés E.M.E., Aldana L.L., Figueroa B., Gutiérrez M.O., Hernández R.M.C., Chavelas M.T. 2005. Trapping of Scyphophorus acupunctatus (Coleoptera: Curculionidae) with two natural baits in a field of Polianthes tuberosa (Liliales: Agavaceae) in the state of Morelos, México. Florida Entomologist 88(3): 338340. DOI: 10.1653/0015-4040(2005)088[0338:TOS $\mathrm{ACW}] 2.0 . \mathrm{CO} ; 2$

Vrdoljak S.M., Samways M.J. 2012. Optimising coloured pan traps to survey flower visiting insects. Journal of Insect Conservation 16(3): 345-354. DOI: $10.1007 / \mathrm{s} 10841-011-9420-9$

Weiss M., Didham R.K., Procházka J., Schlaghamerský J., Basset Y., Odegaard F., Tichechkin A., Schmidl J., Floren A., Curletti G., Aberlenc H.P., Bail J., Barrios H., Leponce M., Medianero E., Fagan L.L., Corbara B., Cizek L. 2019. Saproxylic beetles in tropical and temperate forests - A standardized comparison of vertical stratification patterns. Forest Ecology and Management 444: 50-58. DOI: 10.1016/j.foreco.2019.04.021

Wermelinger B., Flückiger P.F., Obrist M.K., Duelli P. 2007. Horizontal and vertical distribution of saproxylic beetles (Col., Buprestidae, Cerambycidae, Scolytinae) across sections of forest edges. Journal of Applied Entomology 131(2): 104-114. DOI: 10.1111/j.1439-0418.2006.01128.x

Williams R.N., Ellis M.S., Keeney G. 1995. A Bait Attractant Study of the Nitidulidae (Coleoptera) at Shawnee State Forest in Southern Ohio. Great Lakes Entomologist 27(4): 229-234.

Wong J.C.H., Hanks L.M. 2016. Influence of fermenting bait and vertical position of traps on attraction of cerambycid beetles to pheromone lures. Journal of Economic Entomology 109(5): 2145-2150. DOI: 10.1093/jee/tow 197

Worthington R.J., Larsen K.J. 2010. An annotated checklist of scarab beetles (Coleoptera: Scarabaeidae) from Northeastern Iowa. Great Lakes Entomologist 43(1-4): 77-90.

$\mathrm{Xu}$ W. 2019. How do moth and butterfly taste? - Molecular basis of gustatory receptors in Lepidoptera. Insect Science 27: 1-10. DOI: 10.1111/1744-7917.12718

Yang K.L., Wen X.J., Zhang G.Y., Wen J.B. 2019. Evaluation of trap designs and food attractants for trapping Eucryptorrhynchus scrobiculatus (Coleoptera: Curculionidae). Biocontrol Science and Technology 29(1): 28-43. DOI: 10.1080/09583157.2018.1525483 


\title{
ПРИМЕНЕНИЕ ПРОСТЫХ КРОНОВЫХ ЛОВУШЕК ДЛЯ СБОРА НАСЕКОМЫХ
}

\author{
А. Б. Ручин ${ }^{1}$, Л. В. Егоров ${ }^{1,2}$, А. А. Хапугин ${ }^{1,3}$, Н. Е. Вихрев ${ }^{4}$, М. Н. Есин ${ }^{5}$ \\ ${ }^{1}$ Объединенная дирекция Мордовского государственного природного заповедника \\ имени П.Г. Смидовича и национального парка «Смольный», Россия \\ e-mail: ruchin.alexander@gmail.com \\ ${ }^{2}$ Государственный природный заповедник «Присурский», Россия \\ e-mail:platyscelis@mail.ru \\ ${ }^{3}$ Тюменский государственный университет, Россия \\ ${ }^{4}$ Зоологический музей Московского государственного университета, Россия \\ ${ }^{5}$ Ниюегородский государственный педагогический университет имени Козьмы Минина, Россия \\ Приводятся материалы применения простых кроновых ловушек для изучения фауны насекомых. Ловуш- \\ ка представляет собой пластиковую пятилитровую емкость с вырезанным в ней с одном стороны окном \\ на расстоянии 10 см от дна. Высота подвешивания ловушек от 2 м до 10 м от поверхности почвы. В ка- \\ честве приманивающей жидкости использовали бродящее пиво, различные сухие вина с дополнением в \\ виде меда, варенья или сахара. Оказалось, что кроновые ловушки являются эффективным инструментом \\ изучения фауны насекомых верхних ярусов лесов. За сезоны 2018-2019 гг. в кроновые ловушки отлавли- \\ вались предсавители 12 отрядов насекомых: Blattoptera, Dermaptera, Orthoptera, Heteroptera, Coleoptera, \\ Lepidoptera, Trichoptera, Neuroptera, Raphidioptera, Mecoptera, Hymenoptera, Diptera. Для установки луч- \\ ше выбирать места с произрастанием лиственных деревьев, выделяющих сок (Quercus, Acer, Fraxinus, \\ Ulmus, Tilia). Данный тип ловушки можно использовать для изучения вертикального распределения на- \\ секомых в лесных системах, сезонных отловах, при изучении биотопического распределения. Рекомен- \\ дуется применять кроновые ловушки при комплексном обследовании для дополнения стандартных по- \\ левых методов. Такие ловушки при правильном использовании могут быть эффективным инструментом, \\ например, в мониторинге биоразнообразия и или изучении редких видов насекомых. Мы даем следую- \\ щие рекомендации для исследования энтомофауны с помощью кроновых ловушек: 1) очень важно опре- \\ делить количество повторностей и количество ловушек, а также общие усилия по отбору проб; 2) необхо- \\ дима приемлемая таксономическая подготовка для понимания местной фауны; 3) нужно знать местную \\ флору и особенно лесные массивы с произрастающими в них видами деревьев; 4) нужно определить для \\ себя задачу исследования (всю фауну данной местности или фауну отдельных групп), от которой зависит \\ выбор места и высоты расположения ловушек; 5) в качестве приманки лучше использовать сахар и мед; \\ 6) для оптимальных результатов отлова нужно определить состав смеси приманки, высоту и место рас- \\ положения ловушек; 7) время экпозиции не должно превышать 7-8 суток в летние месяцы.
}

Ключевые слова: Arthropoda, метод сбора насекомых, насекомые, привлекающая жидкость, привлечение, приманка на пиво 